\title{
Je li papa Franjo katolik?
}

\section{Tonči Matulić*}

tonci.matulic@kbf.unizg.hr

https://orcid.org/0000-0003-3419-9938 https:/doi.org/10.31192/np.19.2.3

UDK: 272-732.2Franciscus, papa 272 " 20 “

Pregledni članak / Review Primljeno: 27. travnja 2021. Prihvaćeno: 20. lipnja 2021.

Članak je prošireno te izvorima i literaturom opremljeno predavanje pod naslovom »Je li papa Franjo katolik?«, održano 21. travnja 2021. godine na društvenim mrežama Hrvatskoga nadzemlja, službenog projekta Ureda za mlade Splitsko-makarske nadbiskupije. Autor u članku pokazuje i dokazuje da pitanje »Je li papa Frano katolik? «boluje od medijskog senzacionalizma, s jedne strane, $i$ neutemeljenog $i$ pretjeranog žara za obranom crkvenoga nauka $i$ discipline od, ipak, etički opravdanoga, teološki neupitnoga i ekleziološki prihvatljivoga drukčijeg katoličkog stila i mentaliteta pape Franje, s druge strane. U tom smislu autor u članku predstavlja neke povijesne primjere, upućuje na crkvene učiteljske izvore, posebno na nauk Drugoga vatikanskog koncila, iznosi kritičke teološke analize i nudi prikladne teološke argumente pomoću kojih se razabiru prava narav $i$ motivi zabrinutosti crkvenih kritičara pape Franje. Volja za »osvajanjem prostora Crkve« $i$ čuvanjem statusa quo, ustrajavanje na plitkom uvjerenju »da se tako uvijek radilo«, okamenjeni mentalitet koji odbija poziv na obraćenje i misijsku preobrazbu crkvenih struktura i pastoralnog djelovanja otkrivaju se kao glavne zapreke u prihvaćanju drukčijeg stila, novih gestâ $i$ nekih izjava pape Franje koji ga nedvosmisleno potvrduju zrelim plodom koncilske obnove Crkve i istinskim darom Duha Svetoga Crkvi koja »u vlastitom krilu obuhvaća grješnike te je u isti mah i sveta i potrebna čišćenja - neprestano kroči putem pokore i obnove" (Lumen gentium, 8).

Ključne riječi: papa Franjo, Isus Krist, Duh Sveti, evandelje, vjera, ljubav, milosrđe, siromaštvo, Crkva, Drugi vatikanski koncil, mladi.

\footnotetext{
* Prof. dr. sc. Tonči Matulić, Sveučilište u Zagrebu, Katolički bogoslovni fakultet, Vlaška 38, HR10000 Zagreb.
} 


\section{Uvod}

U mjesecu travnju 2021. godine Hrvatsko nadzemlje iz Splita, kao projekt Ureda Splitsko-makarske nadbiskupije za pastoral mladih, pozvalo me u emisiju, koja se i održala na društvenim mrežama u srijedu 21. travnja 2021. godine, s pitanjem »Je li papa Franjo katolik? « U traženju mog pristanka za sudjelovanje u emisiji uvjeravali su me da to nije pitanje njihova ureda, nego, po njihovim saznanjima, brojnih naših vjernika, podjednako mladih i starih, o čemu bruje razni internetski portali, društvene mreže, tiskovine, crkveni kružoci pa i same gradske ulice. $\mathrm{Za}$ istraživanje tih izvora nismo imali vremena da bismo procijenili njihovu katoličku vjerodostojnost i teološku utemeljenost radi razumijevanja njihove opravdanosti kao i pravih motiva. Ovu činjenicu ne smatramo propustom. Neoprostiv propust bi bio da već ranije nismo pročitali, s dužnim razumijevanjem i otvorenošću, Franjine glavne dokumente u kojima, kao vrhovni poglavar Crkve i učitelj vjere i morala, izlaže vlastite poglede i naglaske crkvenoga nauka i obnove što ih smatra ključnima za sadašnji život i poslanje Crkve. Kronološkim redom objavljivanja to su posebno dokumenti: enciklika Lumen fidei - Svjetlo vjere, ${ }^{1}$ apostolska pobudnica Evangelii gaudium - Radost evandelja, ${ }^{2}$ bula najave Izvanrednoga jubileja milosrda Misericordiae vultus Lice milosrda, ${ }^{3}$ enciklika Laudato sì - Hvaljen budi, ${ }^{4}$ posinodska apostolska pobudnica Amoris laetitia - Radost ljubavi, ${ }^{5}$ apostolsko pismo na zaključenju Izvanrednoga jubileja milosrđa Misericordia et misera - Milosrde i jadnica, ${ }^{6}$ apostolska pobudnica Gaudete et exultate - Kličite i radujte se, ${ }^{7}$ posinodska apostolska pobudnica Christus vivit - Krist živi, ${ }^{8}$ posinodska apostolska pobudnica Querida Amazonia - Ljubljena Amazonija, ${ }^{9}$ enciklika o bratstvu i socijalnom prijateljstvu Fratelli tutti. ${ }^{10}$

${ }^{1}$ Usp. Papa FRANJO, Lumen fidei - Svjetlo vjere. Enciklika o vjeri, (29. lipnja 2013.), Zagreb, Kršćanska sadašnjost, 2013, [dalje LF].

2 Usp. Papa FRANJO, Evangelii gaudium - Radost evandelja. Apostolska pobudnica o naviještanju evanđelja u današnjem svijetu, (24. studenoga 2013.), Zagreb, Kršćanska sadašnjost, 2013, [dalje EG].

${ }^{3}$ Usp. Papa FRANJO, Misericordiae vultus - Lice milosrda. Bula najave Izvanrednoga jubileja milosrđa, (11. travnja 2015.), Zagreb, Kršćanska sadašnjost, 2015, [dalje MV].

${ }^{4}$ Usp. Papa FRANJO, Laudato si - Hvaljen budi. Enciklika o brizi za zajednički dom, (24. svibnja 2015.), Zagreb, Kršćanska sadašnjost, 2015, [dalje LS].

${ }^{5}$ Usp. Papa FRANJO, Amoris laetitia - Radost ljubavi. Enciklika o ljubavi u obitelji, (19. ožujka 2016.), Zagreb, Kršćanska sadašnjost, 2016, [dalje AL].

${ }^{6}$ Usp. Papa FRANJO, Misericordia et misera - Milosrde i jadnica. Apostolsko pismo na zaključenju Izvanrednoga jubileja milosrđa, (20. studenoga 2016.), Zagreb, Kršćanska sadašnjost, 2017, [dalje MM].

7 Usp. Papa FRANJO, Gaudete et exultate. Apostolska pobudnica o pozivu na svetost u suvremenom svijetu, (19. ožujka 2018.), Zagreb, Kršćanska sadašnjost, 2018, [dalje GE].

${ }^{8}$ Usp. Papa FRANJO, Christus vivit - Krist živi. Posinodska apostolska pobudnica mladima i cijelome Božjem narodu, (25. ožujka 2019.), Zagreb, Kršćanska sadašnjost, 2019, [dalje ChV].

9 Usp. Papa FRANJO, Querida Amazonia - Ljubljena Amazona. Posinodska apostolska pobudnica, (2. veljače 2020.), Zagreb, Kršćanska sadašnjost, 2020, [dalje QA].

${ }^{10}$ Usp. Papa FRANJO, Fratelli tutti. Enciklika o bratstvu i socijalnom prijateljstvu, (3. listopada 2020.), II. izdanje, Zagreb, Kršćanska sadašnjost, 2021, [dalje FT]. 


\section{1. »Neće u kraljevstvo nebesko ući svaki koji mi govori: 'Gospodine, Gospodine!'«(Mt 7,21)}

Ako je pitanje: Je li papa Franjo katolik? trebalo izvršiti funkciju medijske atraktivnosti, neke vrste senzacionalizma, onda ga u tom slučaju nije trebalo ni postaviti. Komu se čini normalnim i prihvatljivim da propovjednik nedjeljom stane za propovjedaonicu i pita se, primjerice, je li Isus iz Nazareta Sin Božji? Ili da se pita vjeruje li naš mjesni biskup u Boga? U slavlju u kojemu se hrani i izgrađuje Crkva kao zajednica Kristovih učenica i učenika ne postavljaju se otrovna pitanja koja ne pružaju zdravu hranu, niti se primjenjuje logika destrukcije koja razgrađuje jedinstvo i zajedništvo Crkve.

Budući da Hrvatsko nadzemlje posebno okuplja mlade i obraća se mladima čovjek bi očekivao da su zajedno s mladima, svatko osobno i zajednički u svojim župnim zajednicama, pročitali i raspravljali o naglascima iz posinodske pobudnice Christus vivit - Krist živi koju je papa Franjo uputio upravo njima, ali i cijelom Božjem narodu na svetkovinu Blagovijesti 2019. godine. Stoga nas golica pitanje koliko je naših mladih katolika pročitalo sadržajnu i poučnu pobudnicu Krist živi? Čovjek bi se bio osjećao daleko opuštenije i pozvanije da je spomenuta emisija bila posvećena zajedničkom promišljanju o Franjinim porukama mladima, upoznavanju njegove vizije uloge mladih u Crkvi i njegovih očekivanja od mladih u obnovi Crkve i svjedočenju evanđelja, nego što smo se bavili tamnim sjenama provokativnoga i dubioznog pitanja katoličke vjerodostojnosti aktualnoga rimskog prvosvećenika pape Franje.

Kako bilo, sve da smo i poduzeli nemoguću misiju i proučili sve medijski izražene zabrinutosti o djelovanju pape Franje, svejedno ne bismo bili pronašli spokoj usred nelagode koju nam je uzrokovalo neprimjereno pitanje je li papa Franjo katolik? Kakva je narav i oštrica ovog pitanja, može se shvatiti na temelju nekoliko analognih pitanja: Je li naš nadbiskup katolik? Je li naš župnik ili duhovnik katolik? Što je ostalo od katoličkoga na našem Katoličkom bogoslovnom fakultetu? Ne vrti im se valjda svima aureola svetosti oko glave koja otklanja svaku pa i najmanju sumnju u njihovu besprijekornu i neupitnu katoličku vjerodostojnost? Ovako postavljena pitanja nikamo ne vode. Ona od početka i u temelju podrivaju osobu ili ustanovu, unaprijed izražavaju sumnju u njihovu katoličku vjerodostojnost koja uostalom ovdje na zemaljskom proputovanju nikad nije savršena, ni apsolutna, nego se nalazi u stalnome procesu obnove, odrastanja i usavršavanja. S oštricom ovakvog pitanja svakome u Crkvi ne preostaje ništa drugo nego braniti svoju čast i integritet »na život i smrt«. U takvom ozračju nije moguća trijezna i staložena rasprava o ovom ili onom proble$\mathrm{mu}$, ako problema ima, nego se stvara ozračje »ratnoga stanja« koje neizbježno uzrokuje i žrtve. Komu su potrebne dodatne žrtve u Crkvi, osim onih brojnih žrtava seksualnoga zlostavljanja počinjenog od samih crkvenih službenika? 
Teško je zatomiti žaljenje da smo se u našoj hrvatskoj katoličkoj sredini, koja je u katoličkome svijetu veoma dobro poznata upravo po odanosti i ljubavi prema rimskome prvosvećeniku i poglavaru Katoličke crkve, nasukali u plićaku površnih i jednostranih, a često i zlonamjernih pogleda i shvaćanja stila, gesta i izjava pape Franje do granice da ga se sumnjiči je li uopće katolik, a sve to s punim ustima brige za dobro Crkve. No, evanđeosku istinu nitko ne može dokinuti. Stoga puko uzvikivanje »Gospodine, Gospodine!« ne garantira i vršenje Gospodinove volje (usp. Mt 7,21-23).

Moglo bi se pomisliti da smo u proturječju sa samima sobom, jer odakle su nam poznate zabrinutosti zbog pape Franje ako nismo upoznati sa svim hrvatskim medijskim napisima koji njima vrve? Poznato nam je iz sad već teško sagledivoga broja stranih knjiga i napisa u kojima se bezočno odapinju otrovne strelice kritikâ i nabacuje blatom svakovrsnih ružnih etiketa na papu Franju, od toga da je heretik, mason, siledžija, diktator, globalist, teološki nepismen, licemjeran i tako redom, ${ }^{11}$ ali još prije toga iz susreta i razgovora $\mathrm{s}$ brojnom hrvatskom subraćom svećenicima. Neka se čudna i vjerskom razumu neshvatljiva odbojnost uvukla u neku od naše subraće prema papi Franji. Zašto je to tako? Predmnijevamo zato što papa Franjo, kao nijedan papa u novijoj povijesti Crkve, otvoreno govori o mračnim stranama i zastranjenjima klerikalizma u Crkvi. ${ }^{12}$ Možemo shvatiti da je kler zatečen baš papinom otvorenom kritikom klerikalizma. No, ako je itko u Crkvi pozvan to činiti, onda je to upravo papa, budući da je njegov dvor začetnik i promicatelj takozvane »kleričke kulture«. Neshvatljivo je pritom da svećenici sami ne uviđaju teška i bolna zastranjenja u vlastitim redovima o kojima papa Franjo otvoreno progovara. Istine radi, papa Franjo redovito i neizostavno poziva na nužnu preobrazbu i osobno obraćenje, na neodgodivu obnovu crkvenih i pastoralnih strukturâ. Komu smeta poziv na osobno obraćenje i obnovu Crkve?

Iz crkvenoga nauka znamo da se »istina ne nameće drukčije doli snagom same istine koja u dušu ulazi istodobno i blago i snažno $\aleph^{13}$ pa se slijedom toga ovdje vodimo načelom da se istina ne može ni braniti drukčije doli snagom same istine koja istodobno ulazi blago i snažno u dušu, ali pritom valja jasno reći, da istina može ući samo u dušu koja je otvorena istini, koja iskreno traži

\footnotetext{
${ }^{11}$ Duga je lista djela u kojima se otvoreno kritički i čak brutalno napada papu Franju sa svih strana spektra ideologizirane vjere, ali i iz nekih svjetovnih krugova. Izdvajamo samo nekoliko najbombastičnijih naslova koji ne zaslužuju našu reklamu, ali imajući u vidu da će nas samo istina osloboditi i da vjera traži razumijevanje, onda držimo da je itekako korisno poznavati pamflete protiv pape Franje. O tome v. Marcantonio COLONNA [Henry SIRE], The Dictator Pope. The Inside Story of the Francis Papacy, Washington, D.C., Regnery Publishing, 2017; Philip F. LAWLER, Lost Shepherd. How Pope Francis is Misleading His Flock, Washington, D.C., Regnery Publishing, 2018; Taylor MARSHALL, Infiltration. The Plot to Destroy the Church from Within, Manchester (NH), Sophia Institute Press, 2019.

${ }^{12}$ Usp. EG, 93-97; ChV, 95-102.

${ }^{13}$ Deklaracija Dignitatis humanae o slobodi vjerovanja, (7. prosinca 1965.), u: DRUGI VATIKANSKI KONCIL, Dokumenti, 7. popr. i dop. izd., Zagreb, Kršćanska sadašnjost, 2008, 1, [dalje $\mathrm{DH}]$.
} 
istinu, koja zna da jedino istina posjeduje moć oslobođenja od grijeha, predrasuda, stereotipova i tabua (usp. Iv 8,32). Oštrica pitanja je li papa Franjo katolik sugerira da je onima koji ga postavljaju istina već poznata, dakle da je papa Franjo, ako ne otpao od katoličkoga zajedništva, onda se barem dramatično približio kritičkoj točki otpadništva. U suprotnom, kojem bi dobronamjernom katoliku uopće palo na pamet pitati se je li »rimski prvosvećenik, kao namjesnik Kristov i pastir cijele Crkve, koji ima u Crkvi punu, vrhovnu i opću vlast koju može uvijek slobodno vršitii ${ }^{14}$ katolik?

Možda je posrijedi nešto daleko benignije i prizemnije. Naime, budući da smo naviknuti na pape europskoga stila i mentaliteta jednostavno se ne snalazimo s papom s drugog kontinenta? No, tada nam se oštrica pitanja »Je li Papa katolik? « vraća s oštricom protupitanja: Jesmo li mi uistinu katolici, ako smo katoličku narav Crkve poistovjetili s europskim stilom i mentalitetom papinske i svake druge crkvene službe? Jer, katolička narav Crkve nije ni europska, ni latinoamerička, ni afrička, ni azijska, nego upravo sveopća, sve-obuhvatna, svenatkriljujuća, sve-uključujuća.

»Crkva, živeći tijekom vremenâ u različitim okolnostima, primjenjivala je stečevine raznih kultura da bi u svojem propovijedanju kod svih naroda proširila $\mathrm{i}$ istumačila Kristovu poruku, (...). No u isto se vrijeme Crkva, poslana svim narodima svih vremena i krajeva, ne navezuje isključivo i nerazrješivo ni na koju rasu ili narod, ni uz koji poseban način života i ni uz bilo koji stari ili novi običaj. Prianjajući uz svoju vlastitu predaju i istodobno svjesna svojega sveopćeg poslanja, ona može stupiti u zajedništvo s raznim oblicima kulture. Time se obogaćuje i sama Crkva kao i te različite kulture. $^{15}$

U svjetlu ove koncilske izjave samo zlonamjerni mogu sumnjičiti papu Franju zbog njegova zakonitoga osobnog i partikularnog katoličkog stila i mentaliteta u vršenju papinske službe.

Papa Franjo, kao čovjek s drugoga kraja svijeta, kao nadbiskup i metropolita buenosaireski, kao Argentinac i Latinoamerikanac, ima puno i neotuđivo pravo pokazivati katoličku narav Crkve na sebi svojstven način. Dakako, to apsolutno isključuje svojeglavost i samovoljnost, ali treba uključivati zakonit osobni način što ga je on u svom vjerničkom odrastanju i pastirskom životu naučio kod sebe doma u Argentini, u kojoj postoji i djeluje zakonita partikularna Katolička crkva. S time smo, ako već ne zakoračili u srce problema, onda svakako došli pred samo srce problema. Naime, sa svom ozbiljnošću, ali i s neuklonjivom i neizbježnom nelagodom, uzimamo oštricu pitanja je li papa Franjo katolik i, istine radi, istom oštricom tražimo odgovor na njega tamo gdje ga možemo pronaći, a to je dvomilenijska katolička tradicija Crkve i papinstva.

\footnotetext{
${ }^{14}$ Dogmatska konstitucija Lumen gentium o Crkvi, (21. studenoga 1964.), u: DRUGI VATIKANSKI KONCIL, Dokumenti, 22, [dalje LG].

${ }^{15}$ Pastoralna konstitucija Gaudium et spes o Crkvi u suvremenom svijetu, (7. prosinca 1965.), u: DRUGI VATIKANSKI KONCIL, Dokumenti, 2; 58, [dalje GS].
} 


\section{2. »Neizbježno dolaze sablazni, ali jao čovjeku po kom dolazi sablazan« $(M t$ 18,7)}

Dobro su nam poznati životi ogromne većine papa, njih do danas ukupno 266. Papinstvo sve i da hoće ne može sakriti samo sebe, podjednako svoju veličinu, ali nažalost i svoju bijedu, jer zajedno s Kristovom Crkvom papinstvo je jedina institucija na licu Zemlje koja ne samo da traje već 2000 godina, nego sve bilježi i pamti u dokumentima i aktima koji se pohranjuju i brižno čuvaju, a što predstavlja tvarnu osnovu Pologa vjere (Depositum fidei). U tom smislu vjernik se katolik oštricom istoga postavljenog pitanja može danas s pravom okrenuti Rodrigu de Borgi (1431.-1503.) ili papi Aleksandru VI. (1492.-1503.) i upitati se je li on bio katolik, kao i brojni drugi renesansni pape, a za kojega je dobro poznato da je živio častohlepnim, hedonističkim i gotovo razvratnim životom?

Današnji vjernik bi se mogao oštricom istoga pitanja zapitati je li Giovanni Maria Mastai Ferretti (1792.-1878.) ili papa Pio IX. (1846.-1878.) bio katolik koji je osudio kao zabludu stav »da više nije korisno katoličku religiju smatrati za jedinu državnu religiju« ${ }^{16}$ Koji katolik danas drži ispravnim da Katolička crkva treba biti jedina priznata državna religija? Također je osudio kao zabludu i stav da »svaki čovjek ima slobodu prihvatiti i ispovijedati religiju, za koju, vođen svjetlom razuma, bude smatrao da je istinita «. ${ }^{17}$ Koji katolik danas ne smatra da je pravo na slobodu savjesti i vjeroispovijesti temeljno i utoliko neotuđivo ljudsko pravo, jer kako nas uči Koncil »istinu valja tražiti na način svojstven dostojanstvu ljudske osobe i njezinoj društvenoj naravi«, a »zapovijedi božanskoga zakona čovjek, dakako, shvaća i prihvaća posredstvom svoje savjesti«; pa slijedom toga »ne smije biti prisiljen postupati protiv svoje savjesti, ali se ne smije sprječavati da postupa po svojoj savjesti, napose u stvarima vjerovanja «. ${ }^{18}$

Današnji vjernik bi se oštricom istoga pitanja mogao zapitati je li Joseph Ratzinger (1927.) ili papa u miru Benedikt XVI. (2005.-2013.) katolik koji je 28. veljače 2013. godine abdicirao od papinske službe, a po načinu izvedbe svoje odluke kao prvi papa u povijesti Crkve, uz jednostavno obrazloženje da ga izdaju ljudske snage i da na svojim staračkim ramenima više ne može nositi teret papinske službe. ${ }^{19}$ Rimska kurija, kao složeni administrativni i birokratski organ Svete Stolice, neposredna je pomoć papi u upravljanju sveopćom Crkvom, a broji nekoliko tisuća zaposlenih službenika. Je li Benedikt XVI. abdicirao zato što mu je masa zaposlenika Kurije uskraćivala dužnu pomoć u upravljanju

\footnotetext{
${ }^{16}$ PIO IX., Syllabus - Zbirka zabluda, (8. prosinca 1864.), u: Heinrich DENZINGER, Peter HÜNERMANN, Zbirka sažetaka vjerovanja, definicija i izjava o vjeri i ćudoređu, Đakovo, Karitativni fond »U pravi trenutak«, 2002, [77.] 2977.

${ }^{17}$ Isto, [15.] 2915.

${ }^{18} \mathrm{DH}, 3$.

${ }^{19}$ Usp. BENEDIKT XVI., Declaratio, (10. veljače 2013.), http://www.vatican.va/content/benedict-xvi/it/speeches/2013/february/documents/hf_ben-xvi_spe_20130211_declaratio.html (20.04.2021).
} 
Crkvom ili zato da bi se, intimno razočaran, sklonio podalje od afera i teških zloporaba službi svojih suradnika koje su potresale Crkvu?

Oštricom istoga pitanja bismo se mogli zapitati je li Karol Józef Wojtyła (1920.-2005.) ili papa Ivan Pavao II. (1978.-2005.) katolik, poznajući detaljno iz službenoga crkvenog izvješća samo jedan slučaj, ponavljamo samo jedan slučaj, briljantne i nikakvim ograničenjima ometane crkvene karijere američkoga svećenika Theodora Edgara McCarricka, kojega je on 1981. godine imenovao prvim biskupom nove biskupije Metuchen u New Jerseyju, zatim 1986. godine imenovao četvrtim nadbiskupom Newarka u New Jerseyju, potom 2000. godine petim nadbiskupom Washingtona, D.C., učinivši ga na kraju u veljači 2001. godine i kardinalom, a kojega je papa Franjo 2019. godine bio prisiljen svesti na laički stalež? Pitanje bi zaista bilo čista provokacija da Državno tajništvo Svete Stolice nije 2020. godine objavilo izvješće na više od 400 stranica $^{20}$ iz kojega je razvidno da je bivši kardinal McCarrick tijekom biskupske službe cijelo to vrijeme koristio, ni manje ni više, nego svoje bogoslove i mlade svećenike za putene naslade, a »pao « je tek 2018. godine kad mu je u kaznenom postupku njegova domicilna nadbiskupija New York dokazala da je kao mladi svećenik počinio i seksualni zločin protiv maloljetnika.

Možda bi našim pobožnim ušima zvučalo nečuveno, da ne kažemo odvratno, kad bismo se upustili u nabrajanje brojnih drugih dobro poznatih slučajeva briljantnih crkvenih karijera i velikih crkvenih uglednika s kraja 20. i početka 21. stoljeća, a koji se dovode u vezu s raznim nemoralnim radnjama i nepodopštinama, od činjenja i zataškavanja zlodjela pedofilije preko trgovine utjecajima i zloporaba položaja do pranja novca i sumnjivih investicija crkvenoga novca. Mogu li se pred licem evanđelja sve te nepodopštine opravdavati činjenicom da je za vrijeme ranijih crkvenih poglavara obrana katoličkoga pravovjerja bila neupitna? Nije li možda upravo jednostrano i isključivo inzistiranje na pravovjerju (bez ljubavi i samokritičnosti!?) doprinijelo moralnom posrnuću mnogih pojedinaca, ali i cijelih partikularnih krajevnih Crkava u zapadnoj hemisferi? ${ }^{21}$ Dovoljno je prisjetiti se žalosnoga slučaja Marciala Maciela Degollada (1920.2008.), utemeljitelja i desetljećima poglavara (1941.-2005.) pokreta Regnum Christi - Kristovih legionara, koji je upravo radi "poznatoga pravovjerja« bio rado viđen i pozivan u rad tijela i aktivnosti Svete Stolice pa i samoga Ivana Pavla II., a Benedikt XVI. ga je 2006. godine bio prisiljen poslati »u život molitve i pokore bez pojavljivanja u javnosti«. Što se sve doznalo o njemu, ipak, bolje je poštedjeti dušu od tih gadosti. ${ }^{22}$ Istine radi valja također spomenuti i

\footnotetext{
${ }^{20}$ Usp. SEGRETERIA DI STATO DELLA SANTA SEDE (prir.), Rapporto sulla conoscenza istituzionale e il processo decisionale della Santa Sede riguardante l'ex cardinale Thedore Edgar McCarrick (dal 1930 al 2017), Stato della Città del Vaticano, 2020, 447.

${ }^{21}$ Usp. MINISTER FOR HEALTH AND CHILDREN, The Report of the Commission to Inquire into Child Abuse, 2009. Implementation Plan, Dublin, The Stationary Office, 2009.

${ }^{22}$ Usp. J. Paul LENNON, Fr. Marcial Maciel, Pedophile, Psychopath, and Legion of Christ Founder. From Fr. Richard John Neuhaus to Pope Benedict XVI, Second Edition, Kindle, 2012.
} 
bivšega nuncija u SAD-u nadbiskupa Carla Mariu Viganòa, također neupitnih "pravovjernih nazora«, koji je 2018. godine iskoristio krizu oko ex-kardinala McCarricka te je u tri otvorena pisma javno okrivio nikoga drugoga nego papu Franju za podržavanje McCarricka. Pritom je otvoreno pozvao papu Franju da podnese ostavku na službu Petrova nasljednika. ${ }^{23}$ Nadbiskup Viganò se davno prije nadao višem karijernom usponu u Vatikanu, ali su ga 2011. godine papa Benedikt XVI. i kardinal Bertone poslali iz Vatikana u SAD. Upada oči kakvu je podršku i koliki prostor "pravovjerni « Viganò dobio u američkim i europskim ultrakonzervativnim katoličkim medijima. ${ }^{24}$ Sapienti sat!

Afera je pokazala da je i u ovom slučaju orthodoxiae doctrinae disciplinaeque invocatio poslužilo samo kao pokrivalo za izražavanje otvorenog neslaganja s papom Franjom i namjerom da ga se difamira. Ako ovakav neprimjeren i nadasve bezočan obračun jednog pastira Crkve sa svojim vrhovnim poglavarom, papom Franjom, može ikome poslužiti kao podloga za sumnjičenje katoličke vjerodostojnosti pape Franje, onda je to simptom dubljeg problema koji više nema veze $\mathrm{s}$ neumjesnim »ideološkim svrstavanjima« $\mathrm{u}$ Crkvi na konzervativno i progresivno ili nazadno i napredno, nego otkriva mentalitet židovskih svećeničkih i narodnih glavara koji su Isusa na prevaru uhvatili i izručili Pilatu da ga smakne s uvjerenjem »kad on ne bi bio zločinac, ne bismo ga predali tebi« (Iv $18,30)$. To je bilo uvjerenje koje se nije obaziralo na provjerene činjenice i vjerodostojne dokaze, nego se hranilo »pravovjernom« mržnjom i neprijateljstvom prema Isusu koji je javno i otvoreno prokazao njihovu nevjeru i hipokriziju. Njihov stav je bio jasan: »Mi imamo Zakon, i po tom Zakonu on mora umrijeti, jer se pravio Sinom Božjim« (Iv 19,7). Kao što vjerom prihvaćamo da je Isus iz Nazareta uistinu Sin Božji, tako najprije znamo da je Franjo zakonito izabrani rimski biskup i papa, a vjerom prihvaćamo da je 266. Petrov nasljednik i vrhovni poglavar Katoličke crkve.

Zanimljivo je primijetiti da iz usta i pera kritičara pape Franje izlazi na vidjelo neka silna zabrinutost za katoličko pravovjerje i stare katoličke običaje, ali ne i za obraćenje i svjedočenje ljubavi prema bližnjima u svakodnevnom životu. Pritom previđaju da upravo papi, a ne njima, pripada punina vlasti i odgovornosti promicati i čuvati ih. Kao što su židovski svećenički i narodni glavari očitali bukvicu Isusu o pravovjerju - pritom, ni više ni manje, nego ga osudili na smrt - tako se i danas dižu samozvane vojske branitelja katoličkoga

\footnotetext{
${ }^{23}$ Usp. Carlo Maria VIGANÒ, Lettera aperta (1. svjedočenje, 25. kolovoza 2018.), u: http:// www.unavox.it/Documenti/Doc1168_Mons_Vigano_Testimonianza.html\#su (20.04.2021); Carlo Maria VIGANÒ, Scio Cui crediti - So a Chi ho creduto (2 Tim 1,12), (2. svjedočenje, 29. rujna 2018.), https://docplayer.it/126813756-Lettera-dell-arcivescovo-carlo-maria-viganoso-in-chi-ho-creduto.html (20.04.2021); Carlo Maria VIGANÒ, Risposta al cardinale Marc Ouellet (3. svjedočenje, 19. listopada 2018.), https://www.marcotosatti.com/2018/10/19/vigano-risponde-al-card-ouellet-la-terza-testimonianza/ (20.04.2021).

${ }^{24} \mathrm{O}$ tome više: Tonči MATULIĆ, Franjina obnova papinstva $i$ Crkve, Zagreb, Kršćanska sadašnjost, 2020, 173-190.
} 
pravovjerja, dijeleći packe i čitajući bukvice papi Franji. Pritom, ni više ni manje, nego ga nazivaju, dakako najnadobudniji među njima, heretikom, ${ }^{25}$ a neki i antikristom. ${ }^{26}$ Upravo to daje najbolju potvrdu ispravnosti stila, gesta i duha pape Franje, budući da nam već elementarno poznavanje katoličke ekleziologije kaže kako je napad na zakonitoga poglavara Crkve napad na samu Crkvu koja se "pokazuje kao 'puk okupljen polazeći od jedinstva Oca i Sina i Duha Svetoga' ${ }^{27}{ }^{27}$

Ako bacanje ružnoga svjetla i sjene na pojedine recentne pape para naše pobožne uši i unosi nemir u naš osjećaj vjere i crkvenosti, a što držimo sasvim primjerenom - upravo katoličkom - reakcijom, pitamo se kako to da, kad je posrijedi papa Franjo, a koji je na Petrovu stolicu izabran neposredno nakon Benedikta XVI. i prije njega Ivana Pavla II., tada uši nekih vjernika odjednom prestaju biti tako pobožne, a vjera gubi snagu ljubavi i osjećaja crkvenosti pa odapinju otrovne strelice kritikâ i nabacuju se blatom svakovrsnih ružnih etiketa i optužbi protiv njega? Uvjereni smo da je to reakcija tvrdokornog i isključivog mentaliteta kojemu kronično nedostaje evanđeoskoga duha, samokritičnosti vjere i ponajviše ljubavi. Posrijedi je logika po kojoj je napad najbolja obrana. To je vjerojatno zato što papa Franjo često, služeći se retoričkom figurom parezije, otvoreno i kritički progovara o nelagodnim i uznemirujućim činjenicama iz crkvenoga života, posebno crkvenih službenika, što mnoge uzrujava, a zasigurno zbog nečiste savjesti ili zbog skrivenih interesa, lagodnosti i sinekura. Kritičari izjavljuju zabrinutost zbog sigurnosti vjere, a papa Franjo izjavljuje zabrinutost zbog zloporaba službe i osobne slobode.

\section{3. »Tako niti je što onaj tko sadi, ni onaj tko zalijeva, nego Bog koji daje rasti $(1$ Kor 3,7)}

Gospodin Isus nam u evanđelju obećava i garantira da će nas samo istina osloboditi (usp. Iv 8,32). U tom svjetlu odapinjanje otrovnih strelica kritikâ i nabacivanje blatom svakovrsnih etiketa na papu Franju nisu i ne mogu biti odraz zrele vjere ni svjedočanstvo zdrave crkvenosti, budući da upravo Franjo pokazuje dužnu snagu i hrabrost istinoljubive vjere i Crkve utemeljene na Istini u prigodnim prokazivanjima i jasnim jezikom nazivanjima pojava u Crkvi koje su zapreka (sablazan, od grč. $\sigma \kappa \alpha v \delta \alpha \lambda$ ov) evanđelju i vjeri, a kao nijedan papa

\footnotetext{
${ }^{25}$ Usp. Nadbiskup Jan LENGA, I won't keep quiet about Pope as 'heretic', (28.02.2020), https:// cruxnow.com/church-in-europe/2020/02/retired-archbishop-in-poland-says-he-wont-keepquiet-about-pope-as-heretic/ (18.04.2021).

${ }^{26}$ Usp. Ricky KING, Pope Francis. The Religious Anti-Christ and the Roman Catholic Church in the Last Days, Kindle Edition, 2015.

${ }^{27} \mathrm{LG}, 4$.
} 
u novijoj povijesti Crkve, iako je istina da ni njegovi predšasnici nisu šutjeli. ${ }^{28}$ Nije lako slušati, a još je teže prihvatiti, govor iz usta jednog pape kojim on svojim najbližim suradnicima otvoreno i iskreno kaže kako se drže i ponašaju te kakav ružan dojam ostavljaju u njegovim očima. ${ }^{29}$ Stvari treba nazvati pravim imenom. U tom smislu iskrenost i otvorenost su poželjne vrline, a prijetvornost i zataškavanje su odbojne mane. Uostalom, papa Franjo je u Vatikan došao s drugoga kraja svijeta i u njemu je zatekao službenike koji trebaju konkretno pokazati da odano i predano služe njemu, dakle papi Franji, u vršenju odgovorne službe Petrova nasljednika, dopuštajući pritom da bude drukčiji papa od prethodnoga koji je njih pozvao i imenovao u kurijalnu službu. Crkva, naime, nije imuna na podjele i svrstavanja. O tome imamo svjedočanstva već u ranoj Crkvi. Apostol Pavao je sasvim iskreno i otvoreno progovorio vjernicima Crkve u Korintu:

»Doista, dok je među vama zavist i prepiranje, zar niste tjelesni, zar po ljudsku ne postupate? Jer, kad jedan govori: 'Ja sam Pavlov', a drugi: 'Ja Apolonov', niste li odveć ljudi?« (1 Kor 3,3-4).

Primjereno »obožavanje« prethodnika nije zabranjeno i može se smatrati normalnim, ali onoliko i do granice koja ne priječi ni psihološki, ni intelektualno, ni duhovno predanost i odanost novome Petrovu nasljedniku, a to na prvome mjestu znači poštivanje i prihvaćanje njegove individualne osobnosti. Jedino je papinska služba trajna, a pape kao pojedinci se mijenjaju. Zbog toga se papinska služba ne može niti smije svesti na mentalitet i stil pojedinoga pape. Upravo je Kurija, koja osigurava kontinuitet vršenja papinske službe, najizloženija napasti da Petrova nasljednika stavi u svoje »kalupe« i to na vrlo prijetvoran način. Izvana mu priznaje punu, vrhovnu i opću vlast (plenitudo potestatis) u Crkvi koju može uvijek slobodno vršiti, ali iznutra, bilo u srcima službenika ili po hodnicima, umišlja da Petrov nasljednik može i smije nešto relevantno poduzeti i učiniti jedino po njihovu diktatu i smjernicama. Tko je onda vrhovni poglavar Crkve: Petrov nasljednik ili Kurija?

Držimo da je upravo u ovu stupicu upao bivši prefekt Kongregacije za nauk vjere kardinal Gerhard Ludwig Müller kojemu se papa Franjo 2017. godine, valja priznati neočekivano, zahvalio na spomenutoj službi. Razlog tomu možda treba tražiti u neprilagođenoj svijesti po kojoj je mislio da je važniji od pape, jer je na čelu vatikanske kongregacije za katoličko pravovjerje koje i samog papu obvezuje. Pritom je previdio da je na Petrovu stolicu došao novi papa koji od njega

\footnotetext{
${ }^{28}$ Usp. IVAN PAVAO II., Tertio millennio adveniente - Nadolaskom trećeg tisućljeća. Apostolsko pismo o pripremi Jubileja godine 2000., (10. studenoga 1994.), Zagreb, Kršćanska sadašnjost, 1994, 33-36, [dalje TMA]; BENEDIKT XVI., Svjetlo svijeta. Papa, Crkva i znakovi vremena. Razgovor s Peterom Seewaldom, Split, Verbum, 2010, 32-49.

${ }^{29}$ Usp. PAPA FRANJO, Discorso alla Curia Romana in occasione degli auguri natalizi (22.12.2014), http://www.vatican.va/content/francesco/it/speeches/2014/december/documents/papa-francesco_20141222_curia-romana.html (15.04.2021); vidi također Matulić, Franjina obnova papinstva i Crkve..., 105-110.
} 
ne očekuje ulogu »doktrinarnoga buldoga«, poput njegova učitelja Josepha Ratzingera, kako su ga kolokvijalno zvali, za vrijeme pape sv. Ivana Pavla II. Ne samo to, nego je, slučajno ili ne, a za razliku od kardinala Waltera Kaspera, ${ }^{30}$ koračao mimo pape Franje tijekom održavanja III. izvanredne Sinode biskupa o obitelji u listopadu 2014. godine i XIV. redovite Sinode biskupa o obitelji u listopadu 2015. godine, čime se u crkvenoj javnosti stvorio lažan dojam, a čemu je kumovalo još nekoliko kardinala, da papa Franjo ne poštuje suradnike i neke aspekte katoličkoga nauka. ${ }^{31}$

Svakome je jasno da papa u vršenju odgovorne službe Petrova nasljednika treba organ koji je odavno poznat pod imenom Kurija, ali nije jasno ni prihvatljivo da papa, najprije kao iskusni pastir Crkve, a onda i kao individualna osoba potisne ili, ne daj Bože, dokine vlastitu osobnost, vlastiti stil i mentalitet, podređujući se nekim »ustaljenim« kurijalnim mehanizmima koji svojim stilom i mentalitetom odudaraju od osobnoga stila i mentaliteta novoga pape. U tom smislu je sasvim umjesno pitanje bi li prijedlog pape sv. Ivana XXIII. o sazivanju Drugoga vatikanskog koncila dobio podršku od Kurije kao garanta »nepromjenjivoga« katoličkog nauka? Dobro je poznato s kolikom su nevjericom i zaprepaštenjem nazočni službenici Kurije na blagdan obraćenja sv. Pavla, 25. siječnja 1959. godine, u bazilici sv. Pavla izvan zidina primili najavu Ivana XXIII. o sazivanju sveopćega ekumenskog Koncila u skoroj budućnosti. Na radost mnogih srdaca nisu ga omele ni pokolebale protivne reakcije, nego je svoju namjeru pretočio u obvezujuću odluku. ${ }^{32}$

Imajući pred sobom cijelu povijest papinstva zaista se pokazuje zlonamjernim odapinjanje otrovnih strelica kritikâ i nabacivanje blatom na papu Franju u crkvenim krugovima. On se, nema u to nikakve sumnje, od prvoga časa svog izbora na Petrovu stolicu urbi et orbi pokazao kao drukčiji stilom i mentalitetom od svojih prethodnika. Da se ta njegova "posebnost«, koja pogled očiju vjere redovito usmjerava prema evanđeoskim vrijednostima, odmah dočekuje na oštricu

\footnotetext{
${ }^{30}$ Usp. Walter KASPER, The Gospel of the Family, New York - Mahwah (NJ), Paulist Press, 2014.

${ }^{31}$ Usp. Gerhard Ludwig MÜLLER, Nerazrješivost ženidbe i rasprava o civilno ponovo vjenčanim i sakramentima, u: Roberto DODARO (ur.), Ostati u Kristovoj istini. Ženidba i pričest u Katoličkoj crkvi, Split, Verbum, 2015, 125-138. U društvu kardinala Müllera našli su se i kardinali Walter Brandmüller, Raymond Leo Burke, Carlo Caffara i Velasio de Paolis. Kardinali Brandmüller, Burke i Caffara, a pridružio im se i kölnski kardinal Joachim Meisner, uputili su 19. rujna 2016. godine papi Franji i kardinalu-prefektu Mülleru pismo s pet pitanja (dubbia) povezanih s brojevima 300-305 u posinodskoj pobudnici Amoris laetitia o ljubavi u obitelji, objavljenoj 19. ožujka iste godine. Pitanja nedvosmisleno sugeriraju da izjave pape Franje u tom kontekstu nisu u skladu s tradicionalnim moralnim naukom Crkve. Da tomu nije tako, onda pet pitanja nije trebalo ni postaviti, budući da je svakom dobronamjernom čitatelju više nego jasno na čemu papa Franjo inzistira u navedenim brojevima. To je još prije trebalo biti jasno i uzoritim kardinalima.

${ }^{32}$ Usp. IVAN XXIII., Costituzione apostolica Humanae salutis per l'indizione del SS. Concilio Ecumenico Vaticano II. (25. prosinca 1961.), http://www.vatican.va/content/john-xxiii/ it/apost_constitutions/1961/documents/hf_j-xxiii_apc_19611225_humanae-salutis.html (14.04.2021).
} 
kritike, to sve govori o mentalitetu i stanju svijesti njegovih kritičara. Valja podsjetiti da Crkva priznaje čovjekovo pravo da »sluša siguran sud vlastite savjesti. Kad bi svjesno radio protiv takvog suda, sam bi sebe osudio. ${ }^{33}$ Tko je ovlašten za prosudbu sudova osobne savjesti pape Franje? Sumnjičenje ili čak optuživanje za otpadništvo ili herezu pretpostavlja da je utvrđeno i dokazano da je savjest pape Franje pogrešno formirana ili, blaže, da je u neznanju in rebus fidei et morum »u stvarima vjere i morala « za koje onda treba snositi osobnu odgovornost.

Ako bi se stvari dovodile do apsurda onda bi se moglo zapitati je li se sv. Ivan Pavao II. tri puta prevario što je isusovca Maria Jorgea Bergogliu najprije 1992. godine imenovao pomoćnim biskupom, a 1997. godine nadbiskupom koadjutorom Buenos Airesa te ga 2001. godine učinio kardinalom? Također bi se moglo zapitati je li se dvotrećinska većina od 115 nazočnih kardinala izbornika prevarila što je 13. ožujka 2013. za papu izabrala kardinala Bergoglia? No, posrijedi više ne bi bio čisto etički, ni eklezijalni, nego eminentno teološki problem. Nametnulo bi se pitanje kako se moglo dogoditi da je 2013. godine Duh Sveti zaobišao Sikstinsku kapelu? Tko jednostrano napada i sumnjiči papu Franju za ovo ili ono, neka se radije pobrine za vjerodostojnu, ističemo vjerodostojnu i na stvarnim činjenicama utemeljenu obranu možebitnih promašenih odluka crkvenih poglavara koje su mu omogućile uspon sve do Petrove stolice.

Tijekom povijesti papinstva bilo je pojedinih papa koji su svojim ponašanjem nagrdili čast i dostojanstvo Petrove službe, ali se Crkva nijednoga regularnog nije odrekla, nijednoga od njih nije izbrisala iz popisa niti mu je prekrila mozaički medaljon u bazilici sv. Pavla. No, to nije nikakav argument $u$ prilog papi Franji. Zar nam sama evanđelja ne svjedoče da je problem s vjernošću i vjerodostojnošću postojao već među dvanaestoricom apostola koje je sam Gospodin Isus neposredno i osobno izabrao? Prema tome, posluhom vjere i zrelom razboritošću držimo se Pavlove pouke Korinćanima:

»Tầ što je Apolon? Što je Pavao? Poslužitelji po kojima povjerovaste - kako već kome Gospodin dade. Ja zasadih, Apolon zali, ali Bog dade rasti. Tako niti je što onaj tko sadi, ni onaj tko zalijeva, nego Bog koji daje rasti. Tko sadi i tko zalijeva, jedno su; a svaki će po svome trudu primiti plaću« (1 Kor 3,5-8).

Drugim riječima: Što je Ivan Pavao II.? Što je Benedikt XVI.? Što je Franjo? Dobro su nam poznati njihovi životi, njihova djela i njihovo crkveno služenje. Ali će rasti što su posijali samo ako Bog dade da raste. Jer, »ako Gospodin kuću ne gradi, uzalud se muče graditelji« (Ps 127,1).

Kakvu korist ima sama vjera od jednostrane i krute obrane, ako iz samoga središta vjere znamo da je ona samo ljubavlju djelotvorna (usp. Gal 5,6). Obrana vjere lišena ljubavi ne izvršava dužnost koja proizlazi iz vjere, nego pokazuje vjerski fanatizam. Jednostrana i kruta obrana vjere - i to još, ni više ni manje,

${ }_{33}^{3}$ KATEKIZAM KATOLIČKE CRKVE, Hrvatska biskupska konferencija, Zagreb, Glas Koncila, 1994, 1790, [dalje KKC]. 
nego uperena protiv aktualnoga vrhovnog poglavara Crkve pape Franje - teško može sakriti neke osobne interese i nadasve manjak ljubavi. Vjera je samo ljubavlju djelotvorna i, posljedično, obrana vjere bez ljubavi koja zahtijeva prostor osobne slobode jest vjerski fundamentalizam. Apostol Pavao nas poziva da

»istinujući u ljubavi poradimo te sve uzraste u Njega, koji je Glava, Krist, od kojega sve Tijelo, usklađeno i povezano svakovrsnim zglobom zbrinjavanja po djelotvornosti primjerenoj svakom pojedinom dijelu, promiče svoj rast na saziđivanje u ljubavi« (Ef 4,15-16).

Crkva se, dakle, gradi i brani ljubavlju koju posreduje vjera, a ne naučenim vjerskim formulama i riječima ljudske mudrosti.

»Kad bih sve jezike ljudske govorio, i anđeoske, a ljubavi ne bih imao, bio bih mjed što ječi ili cimbal što zveči. Kad bih imao dar prorokovanja i znao sva otajstva i sve spoznanje; i kad bih imao svu vjeru, da bih i gore premještao, a ljubavi ne bih imao - ništa sam!« (1 Kor 13,1-2).

Ne postoji kršćanska vjera koja, bilo u sadržaju bilo u načinu izlaganja, postoji bez ljubavi. Samo smo u ljubavi predodređeni za posinstvo u Isusu Kristu (usp. Ef 1,2). Tko to među nama smije vjerodostojno tvrditi da ljubi Krista, da ljubi njegovu Crkvu, da ljubi Kristove sestre i braću, a pritom smatra opravdanim pitanje je li papa Franjo katolik? Papa je najvidljiviji znak jedinstva Crkve i najodgovorniji za čuvanje zdrave vjere i izgradnju Crkve u ljubavi.

\section{4. »Nosi se od mene, sotono! Sablazan si mi, jer ti nije na pameti što je Božje, nego što je ljudsko!'«(Mt 16,23)}

Držimo također da u ovom kontekstu nije na odmet prisjetiti se jedne od najozbiljnijih i najdramatičnijih opomena koju je Gospodin Isus uputio, ni više ni manje, nego apostolu Petru i to neposredno nakon što je Petar kod Cezareje Filipove ispovjedio vjeru u Isusa kao »Krista - Pomazanika, Sina Boga živoga « (Mt 16,16): »Isus se okrene i reče Petru: 'Nosi se od mene, sotono! Sablazan si mi, jer ti nije na pameti što je Božje, nego što je ljudsko!'« (Mt 16,23). Petar je Isusa čas prije pukom ljudskom logikom odvraćao od muke i smrti u Jeruzalemu (usp. Mt 16,22). Pritom treba sasvim dokraja raščistiti stvar. Naime, Petrova ispovijest vjere u Sina Božjega je najmanje Petrova. Ona je eminentno Božje djelo u Petru. Stoga valja jasno i otvoreno reći, Petar i Pavao i svaki drugi učenik u Novome zavjetu relevantan je za vjeru i Crkvu utoliko što je prožet božanskom vjerom Isusa Krista, što njegov ljudski život isijava jedinim istinskim životom Isusa Krista, što njegovo ponašanje i djelovanje odražava ponašanje i djelovanje Isusa Krista koji ga je pozvao i uvrstio među svete i izabrane svoje (usp. Iv 15,1617), koji je za njega iz ljubavi svoj život predao (usp. Gal 2,20; Iv 10,1-15), koji ga je učinio novim stvorenjem iz vode i Duha Svetoga (usp. Iv 3,6-7; 2 Kor 5,17; Gal 
6,15), koji je u njega položio riječ i službu pomirenja (usp. 2 Kor 5,19-21), koji ga je poslao da propovijeda evanđelje svemu stvorenju (usp. Mk 16,15).

Kad Isusov učenik, bio on apostol Petar ili zadnja bakica u nekom zabačenom selu, ispovjedi božansku vjeru, tada zaslužuje ove Gospodinove riječi: »Nato će mu Isus: 'Blago tebi, Šimune, sine Jonin, jer ti to ne objavi tijelo i krv, nego Otac moj, koji je na nebesima'« (Mt 16,17). Međutim, Isus ga ovdje čak ne zove Petrom, nadimkom što mu ga je upravo Isus dao (usp. Mt 16,18), ukazujući na njegovu tvrdoglavost (stijena), nego ga zove njegovim osobnim imenom Šimun, da bi time podebljao i potvrdio da vjera koju je upravo ispovjedio isključivo dolazi od Boga i zbog toga je eminentno božanska. Treća potkrepa božanskoga podrijetla i naravi vjere dolazi s dozivanjem Šimunova oca Jone, a čije ime upućuje na starozavjetnoga proroka Jonu kojega Biblija pamti kao jedinoga proroka koji je odbio poslušati zapovijed Gospodina Boga (usp. Jon 1,1-2).

Isusov strogi ukor Petru, apage satanas, nameće pitanje što jest Petrovo pravovjerje? Trebamo li ga tražiti u Petrovu stilu što mu ga je uvjetovao nagao temperament galilejskoga ribara? Trebamo li ga tražiti u Petrovu odvraćanju Isusa od muke i smrti koje mu je priskrbilo Učiteljev strogi prijekor? Trebamo li ga tražiti u Petrovoj bojažljivoj vjeri koja mu je dopustila tri zatajenja Učitelja? Trebamo li ga konačno tražiti u Petrovu židovskom podrijetlu i njegovu obiteljskom rodoslovlju? Na svu sreću svih koji ispovijedaju vjeru u Isusa Krista Sina Božjega i njegovo evanđelje, Petrovo pravovjerje ne trebamo tražiti ni u čemu od navedenoga, nego, kako nas Crkva uči, u daru

»vjere kojom čovjek potpuno podlaže Bogu svoj razum i svoju volju. Čovjek daje svoj pristanak Bogu objavitelju svim svojim bićem (usp. Dei Verbum, 5). Taj čovjekov odgovor Bogu objavitelju Sveto pismo naziva 'poslušnošću vjere' (usp. $\operatorname{Rim} 1,15 ; 16,26) \ll^{34}$

I pored svih Petrovih slabosti i posrnuća, Isus ga se nije odrekao.

Nemilosrdni kritičari pape Franje umišljaju da im jednostrana obrana vjere i Crkve ipso facto daju Božje oči kojima jasno i nedvosmisleno vide Franjinu nutrinu, njegov razum i volju koji se, eto, potpuno ne podlažu Bogu i Kristu, vide ključan detalj da on makar nekim dijelom svoga bića ne daje osobni pristanak Bogu objavitelju svim svojim bićem, vide da on Bogu Isusa Krista ne odgovara posluhom vjere pa im se slijedom svega toga pričinja, štoviše, nekima je čak kristalno jasno kao dan, da Franjina papinska mantija, njegov stil, geste i riječi skrivaju heretika, smutljivca, svojeglavca, dodvoricu is čime li ga već ne etiketiraju. Ali to nije moguće. Jer promatrati ljude i fenomene Božjim očima znači nešto sasvim drugo, dotično upravo suprotno od onoga što čine Franjini kritičari. Neka bude, ali nipošto ne tek usputno, spomenuto kako Bog promatra čovjeka:

»Ne sudite da ne budete suđeni! Jer sudom kojim sudite bit ćete suđeni. I mjerom kojom mjerite mjerit će vam se. Što gledaš trun u oku brata svojega, a brvna u oku svome ne opažaš« (Mt 7,1-3).

${ }^{34} \mathrm{KKC}, 143$. 
Neka bude spomenut i detalj iz crkvenoga nauka:

»Bog, naime, gleda na dostojanstvo ljudske osobe koju je sam stvorio i koja mora biti vođena vlastitom odlukom i uživati slobodu. A to se najviše pokazalo u Isusu Kristu, u kojem je Bog savršeno očitovao sebe i svoje puteve. Jer, Krist, koji je naš Učitelj i Gospodin (usp. Iv 13,13), te ujedno blag i ponizan srcem (usp. Mt 11,29), strpljivo je odabrao i pozvao učenike (usp. Mt 11,28-30; Iv 6,67-68). On je, istina, čudesima podupirao i potvrđivao svoje propovijedanje kako bi pobudio i pojačao vjeru slušateljâ, a ne da na njih vrši pritisak (usp. Mt 9,28-29; Mk 9,23-24; 6,5-6). Nevjeru slušateljâ je, doduše, korio, ali tako da je kaznu ostavljao Bogu za Sudnji dan (usp. Mt 11,20-24; Rim 12,19-20; 2 Sol 1,8).« «5 $^{35}$

Nitko se, dakle, ne može pozivati na Isusa Krista i tvrditi da mu nije jasna razlika između slobode vjere i vjerskog fanatizma, između slobode vjere i vjerskog fundamentalizma. Evanđeosku istinu nije moguće dokinuti: »T囚 Bog nije poslao Sina na svijet da on osudi svijet, nego da se svijet spasi po njemu« (Iv 3,$14 ; 12,47)$. Isus svoje učenike nije učio jedno, a on sam radio nešto drugo, nego je u njemu bila savršena podudarnost riječi i djela: »Reče joj Isus: 'Ni ja te ne osuđujem. Idi i odsada više nemoj griješiti'« (Iv 8,11 ).

Ako je oštrica kritike uperena isključivo protiv stila, gesta i nekih prigodnih izjava pape Franje, onda se spontano nameće pitanje koga je Bog u Kristu opunomoćio da proziva, kritizira, napada, moralizira i čak vrijeđa osobu pape Franje? Bit će prije posrijedi odgovor i reakcija na Franjinu pareziju, to jest na otvoreni govor o isključivom i okoštalom mentalitetu nekih vjernika, posebno nekih crkvenih službenika, a kojega nismo navikli slušati iz usta jednoga pape. No, smetnje koje nastaju zbog toga su upitne vrijednosti, jer se pita kako to da nam ne smeta Isusova parezija u evanđeljima ili Pavlova u poslanicama koju je baš on često koristio, ali ne radi puke kritike i provokacije, nego da bi sestre i braću u pojedinim Crkvama opomenuo i pozvao ih da se vrate na put evanđelja. Navodimo samo jedan primjer:

»O bezumni Galaćani, tko li vas opčara? A pred očima vam je Isus Krist bio ocrtan kao Raspeti. Ovo bih samo htio doznati od vas: jeste li primili Duha po djelima Zakona ili po vjeri u Poruku? Tako li ste bezumni? Započeli ste u Duhu, pa da sada u tijelu dovršite? Zar ste toliko toga uzalud doživjeli?« (Gal 3,1-4).

Kad je posrijedi očito zastranjenje od evanđelja i vjere treba najprije posegnuti za bratskom opomenom (usp. Mt 18,15-17), ali ako bratska opomena nije djelotvorna, tada je primjereno posegnuti, kako nas ohrabruje upravo papa Franjo, za retoričkom figurom parezije ili otvorenim kritičkim govorom koji bez uvijanja i okolišanja prokazuje očita zastranjenja i ukazuje na stvarne probleme. Pritom, dakako, nitko nije opunomoćen osuditi i odbaciti ljudsku osobu, nego samo zlodjelo.

${ }^{35} \mathrm{DH}, 11$. 


\section{5. »Antikrist je onaj koji niječe Oca i Sina« (1 Iv 2,22)}

Papa sv. Ivan XXIII., za života prozvan »Dobri«, u nagovoru prigodom svečanog otvaranja Drugoga vatikanskog koncila 11. listopada 1962. godine je izjavio:

»Često se događa, kao što smo doživjeli u svakodnevnom obavljanju apostolske službe, da nam se prenose glasovi nekih koji, i ne bez uvrede našim ušima, iako raspaljeni vjerskim žarom, ipak ne važu stvari pravilno i razborito. Takvi bi naime u sadašnjim prilikama ljudske zajednice htjeli vidjeti samo ruševine i nevolje (...), kao da iz povijesti koja je učiteljica života nemaju što naučiti (...). A nama se čini da se ne smijemo složiti s tim zlokobnim prorocima, koji uvijek najavljuju lošije, kao da je pred vratima smak svijeta. U sadašnjem tijeku ljudskih zbivanja (...) radije treba gledati tajne nakane Božje providnosti koje će tijekom budućih vremena, ljudskom suradnjom, a ponajviše mimo njihova očekivanja, doći do svojega ostvarenja, jer Providnost sve pa i nemila ljudska zbivanja mudro upravlja na dobro Crkve. « ${ }^{36}$

Parafrazirajući izjavu pape sv. Ivana XXIII. u odnosu na sadašnjega papu Franju može se konstatirati sljedeće. Otkako je Mario Jorge Bergoglio, nadbiskup i metropolit Buenos Airesa u Argentini, izbornom voljom 115 nazočnih kardinala u zakonitim konklavama, 13. ožujka 2013. godine izabran za rimskoga biskupa i 266. nasljednika sv. Petra, gotovo pa svakodnevno se događa da u obavljanju apostolske - papinske - službe dolaze glasovi nekih koji, i ne bez uvrede njegovim ušima i svim ljudima dobre volje, mada izvana raspaljeni vjerskim žarom, ipak ne vrednuju stvari pravilno i razborito. Takvi u današnjemu papi Franji i njegovom vršenju papinske službe i odnosu prema svijetu vide samo nevolje, rušenje i, još najgore, hereze, kao da iz dvije milenijske povijesti papinstva nemaju što naučiti, upravo naučiti notornu činjenicu da papa Franjo nije pozvan biti ni kopija, ni klon, ni imitacija bilo kojega od svojih prethodnika, nego po svojoj savjesti kao organu najdubljega iskustva živoga Isusa Krista, raspetoga i uskrsloga, misliti, osjećati i djelovati kao Kristov apostol kojemu je povjerio službu prvenstva u ljubavi (usp. Iv 21,15-18) da učvršćuje svoju braću i sestre $u$ jedinstvu i zajedništvu vjere, nade i ljubavi u njegovoj Crkvi (usp. Lk 22,32).

Uopće nam se ne čini, nego smo najdublje uvjereni da se ne samo ne smijemo, nego nipošto ne možemo složiti sa zlokobnim samozvanim prorocima koji u stilu, gestama i nekim izjavama pape Franje vide samo ili vide uglavnom nešto loše i naopako, nerijetko neki od njih ga poistovjećujući s antikristom i

\footnotetext{
${ }^{36}$ IVAN XXIII., Gaudet Mater Ecclesia. Discorso del Santo Padre alla solenne apertura del Concilio Ecumenico Vaticano II, (11. listopada 1962.), 4.4., http://www.vatican.va/content/john-xxiii/it/speeches/1962/documents/hf_j-xxiii_spe_19621011_opening-council.html (16.04.2021). Ovdje se koristi vlastiti prijevod. Hrvatski prijevod toga govora objavljen je u: Glas Koncila, 2, 28. studenoga 1962., 9-24 te preuzet i ponovno objavljen u: Crkva u svijetu, 47 (2012) 4, 531540 [dalje GME].
} 
likvidatorom Svete Rimske Crkve. »Antikrist je onaj koji niječe Oca i Sina« (1 Iv 2,22). Tko je kada i u kojim okolnostima čuo i pročitao da je papa Franjo zanijekao Oca i Sina? Koliko su optužbe protiv njega ne-evanđeoske i ne-crkvene, svjedoče upravo sveto evanđelje i Crkva na koje se kritičari pozivaju. Umjesto da nakon četiri stotine godina vladavine europskih i talijanskih papa, izuzevši njegova dva predšasnika, sv. Ivana Pavla II. i Benedikta XVI., već u samome izboru pape Franje prepoznamo istinsko djelovanje Duha Svetoga, a onda naročito u njegovu uistinu drukčijem stilu i drukčijim gestama prepoznamo iznenađujuću novost i novo iznenađenje kojima Duh Sveti obnavlja, pomlađuje i vodi Crkvu, neki ustaju raspaljeni vjerskim žarom i brane vjeru od Franjinih odstupanja, ali nipošto ne od katoličkoga nauka, nego od nekih papinskih običaja čisto mondenoga podrijetla, odapinjući otrovne strelice javnih kritika. Neki među njima se čak služe oltarom i ambonom protiv njega. Nasuprot tome držimo da ga je upravo Duh Sveti doveo s kraja svijeta na Petrovu stolicu. Očima vjere nikako ne može promaknuti da taj i takav odnos prema papi Franji najrječitije potvrđuje njegov ispravan hod koji manifestira skrivene nakane Božje providnosti u Crkvi i za Crkvu.

Upravo tijekom budućih vremena, dakako ne bez suradnje brojnih članova Crkve, pokazat će se sva novost i veličina Franjinih gesta, izjava i poruka, a istovremeno sva bijeda njegovih kritičara i osporavatelja. Oni su zabrinuti za sigurnost vjere i Crkve, ali pritom misle samo na svoju osobnu sigurnost, a malo im je stalo do slobode naroda Božjega kojemu u hodu kroz povijest Krist nije dao nikakvu vremenitu sigurnost, nego samo obećanje da će mu jedinu sigurnost pružati i garantirati Duh Sveti i vjernost njegovoj riječi. Prema tome, narodu Božjemu ne treba nikakva lažna sigurnost, to jest sigurnost institucija moći, sigurnost zbijenih redova, sigurnost neproživljenoga pravovjerja, sigurnost logički i racionalno jasno izrečenih disciplinskih tvrdnji, nego mu treba vjerodostojno i autentično svjedočanstvo istinite nesigurnosti koja usred svijeta punog brzih promjena i otvorenih protivljenja živi iz dara vjere koja posreduje ljubav i otkupljenu slobodu (usp. Gal 5,1.13). Pokazat će se, kao što to pokazuje i cijela povijest Crkve, da jedino Duh Sveti kroz Scile i Haribde povijesti vodi Crkvu na putu što joj ga je odredio njezin Gospodin i Glava koji je jedini Put i Istina i Život (usp. Iv 14,6). U tom smislu, da je papa Franjo uistinu dar Duha Svetoga Crkvi najbolje svjedoče upravo njegovi otvoreni, i često nemilosrdni, crkveni kritičari i osporavatelji kojima je na raspolaganju samo jedan pseudoargument, a to je jednostrano i isključivo preuveličavanje dušobrižničke zabrinutosti za očuvanje lažne sigurnosti koja po definiciji skriva osobne interese, a ne interese svetoga naroda Božjega.

Već citirani papa sv. Ivan XXIII. u spomenutom govoru prigodom svečanog otvaranja Koncila također je izjavio:

»Međutim, ne smijemo samo čuvati ovo dragocjeno blago (katoličkoga nauka), kao da se bavimo samo starinom, već, željno, bez straha, moramo nastaviti s 
djelom koje zahtijeva naše doba, nastavljajući put koji je Crkva prošla kroz gotovo dvadeset stoljeća. Stoga se naš posao na prvome mjestu ne sastoji u raspravljanju nekih glavnih tema crkvenoga nauka, podsjećajući detaljnije na ono što su naučavali crkveni oci te stari i moderni teolozi, a što pretpostavljamo da vam je poznato i utisnuto u vaše misli. Da bi se vodile takve rasprave nije bilo potrebno sazvati ekumenski koncil. U sadašnjosti treba naime cjelokupno kršćansko učenje u ovim našim vremenima od svih biti vedrom i mirnom dušom podvrgnuto novom ispitivanju, ništa mu ne oduzimajući, na onaj precizan način razmišljanja i formuliranja riječi koje se prije svega odnose na dokumente Tridentskoga i Prvoga vatikanskog koncila; potrebno je isti nauk preispitati opširnije i temeljitije da bi se duhovi potpunije proželi i informirali, kako to iskreno priželjkuju svi iskreni zagovornici kršćanske, katoličke i apostolske istine; potrebno je da da ovaj siguran i nepromjenjiv nauk, uz kojega se treba vjerno pristajati, produbi i iznese u skladu sa zahtjevima našega vremena. Jedno je uistinu polog vjere, to jest istine sadržane u našem časnom nauku, a drugo je način na koji se one navještaju, uvijek međutim $u$ istom smislu i u istom značenju. Ovoj se metodi mora dati velika važnost i, ako je potrebno, sa strpljenjem je primijeniti; trebat će se naime usvojiti onaj oblik izlaganja koji najviše odgovara učiteljstvu čija je priroda pretežno pastoralna. ${ }^{37}$

U tom je smislu Benedikt XVI. izjavio: »Ivan XXIII. je učinio veliku i neponovljivu gestu kada je sveopćemu Saboru povjerio da riječ Božju danas shvati na nov način. « ${ }^{38}$ Tko shvati Božju riječ na nov način, zasjat će mu i novo svjetlo vjere!

Pošto je sv. Ivan XXIII. pojasnio da je potrebno polog vjere iznijeti u skladu sa zahtjevima našega vremena, dakako u istome smislu i značenju objavljene istine, pred kraj govora je izjavio:

»Ne postoji vrijeme u kojemu se Crkva nije suočavala sa zabludama; često ih je i osuđivala, a ponekad i s najvećom strogoćom. Što se tiče sadašnjeg vremena, Kristova Zaručnica radije koristi lijek milosrđa, nego da posegne za oružjem strogoće; misli da treba ići ususret današnjim potrebama, izlažući razumljivije vrijednost svoga naučavanja radije nego da osuđuje. Ne zato jer nema lažnih nauka, mišljenja i opasnosti od kojih se treba zaštitili i kojima se treba suprotstaviti, nego zato što se svi oni otvoreno suprotstavljaju ispravnim načelima čestitosti i proizveli su takve smrtonosne plodove da se čini kako ih danas ljudi spontano počinju ponovno preispitivati, posebno one oblike postojanja koji ignoriraju Boga i njegove zakone, polažući previše vjere u napredak tehnike, temeljeći dobrobit isključivo na udobnosti života. Sve su svjesniji da je dostojanstvo ljudske osobe i njezino prirodno savršenstvo stvar od velike važnosti i veoma teško dostižno. Važno je prije svega da su iskustvom naučili da vanjsko nasilje nad drugima, moć oružja, politička dominacija apsolutno nisu dovoljni za najbolje rješavanje teških problema koji ih muče.« ${ }^{39}$

\footnotetext{
${ }^{37}$ GME, 6.2.-6.3 i 6.5 .

${ }^{38}$ Benedikt XVI., Svjetlo svijeta..., 83.

${ }^{39}$ GME, 7.2.
} 
Crkva ne želi posezati za oružjem osude raznih zabluda, mišljenja i opasnosti, a kojih je uvijek bilo, ima ih i bit će ih u svijetu, nego na prvome mjestu naviješta poruku koja ne započinje sa zabranama i s »ne«, nego s pozivom na obraćenje radi blizine Božjega kraljevstva (usp. Mk 1,15) i s Božjim »da« čovjeku u Kristu (usp. 2 Kor 1,20). Kristova Zaručnica je opremljena božanskim milosrđem i zato radije poseže za tim lijekom koji najizvrsnije i nenadmašivo izražava Božje »da" grešnome i bezbožnome čovjeku. »Doista, dok mi još bijasmo nemoćni, Krist je, u svoje vrijeme, za nas bezbožnike umro. (...), a Bog pokaza ljubav svoju prema nama ovako: dok još bijasmo grešnici, Krist za nas umrije« (Rim 5,6.8). Dosljedno tome, već i kod površnog zavirivanja u koncilske dokumente lako je uočiti da, za razliku od ranijih dvadeset ekumenskih koncila, dvadeset i prvi ekumenski Drugi vatikanski koncil ne koristi jezik izopćenja i da nikoga nije osudio. Čak se ustegnuo od osude u ono vrijeme najmasovnije zablude ateističkoga komunizma, usprkos peticiji potpisanoj od strane 454 koncilska oca iz 86 zemalja koja je bila predstavljena uoči četvrtoga, zadnjega zasjedanja Koncila 9. listopada 1965. godine. Komunizam se u Europi urušio kao kuća sagrađena na pijesku i bez svečane crkvene osude.

Posrijedi nije promjena crkvenog nauka, nego paradigme crkvenoga odnosa prema svijetu, ali i odnosa unutar samoga naroda Božjega. »Sabor je prije svega preuzeo i ispunio veliku zadaću da iznova definira određenje i odnos Crkve prema novovjekovlju, kao i odnos vjere prema ovome vremenu i njegovim vrjednotama. ${ }^{40}$ Kao mladi teolog ekspert Drugoga vatikanskog koncila Joseph Ratzinger je na kraju prve opće skupštine Koncila 1963. godine izjavio:

»Ako, obazirući se unatrag, pokušamo predočiti si redom te događaje, moramo kazati: na početku Koncila nalazila se stanovita nelagoda i zabrinutost da bi se sve skupa moglo svesti na potvrđivanje unaprijed uobličenih zaključaka što bi nužnoj obnovi Crkve više škodilo nego koristilo; ujedno mnogi bi se razočarali u svojim nadama i postali obeshrabreni, oslabila bi dinamika dobra, a sva ona nova pitanja koja vrijeme postavlja Crkvi opet bi više ili manje bila gurnuta u stranu. « ${ }^{41}$

Na pozitivno ozračje Koncila presudno su utjecali optimizam i jednostavnost dobroga pape sv. Ivana XXIII., ističe Ratzinger, »koji se po tome vidno razlikovao od pape (Pija IX., op. a.) koji je sazvao Prvi vatikanski koncil «. ${ }^{42}$ Drugim riječima, pravo pitanje je:

»Treba li nastaviti s antimodernističkim stavom, pa sve do gotovo bojažljivog odbijanja ili će Crkva, nakon što se pobrine za nužno ograničenje, okrenuti novu stranicu i krenuti prema novom, pozitivnom susretu sa svojim izazovima, sa svojom braćom, s današnjim svijetom? Time što se tako uvjerljiva većina otaca odlučila za drugu alternativu, Koncil je postao novi početak. « ${ }^{43}$

\footnotetext{
${ }^{40}$ Benedikt XVI., Svjetlo svijeta, 83.

${ }^{41}$ Joseph RATZINGER, Prvo zasjedanje Drugoga vatikanskog koncila. Osvrt, Zagreb, Kršćanska sadašnjost, 2008, 7.

${ }^{42}$ Isto, 15.

${ }^{43}$ Isto, 30.
} 
Na samome je Koncilu bilo neupitno - piše Ratzinger - »da se zbivaju duhovni događaji koji žele sazrijevati. (...). Tu je istinski bujalo duhovno susretanje, tu se sazrijevalo uz drugoga is drugim, tu se gledao dio duhovnog kretanja Crkve. «4 A što se tiče pastoralnog usmjerenja Koncila, to nipošto ne znači nebitnost, maglovitost, nepreciznost i puku blagotvornost, kako su to mnogi krivo shvaćali, nego znači da je koncilski nauk - pojašnjava Ratzinger

»formuliran u pozitivnoj brizi za današnjega čovjeka kojemu se ne pomaže osudama, koji je dovoljno dugo slušao što je sve pogrešno i što sve ne smije, a koji je premalo slušao i konačno želi čuti ono što je istinito, s kakvom pozitivnom porukom vjera može nastupiti prema našem vremenu te čemu ga može pozitivno poučavati i što mu pozitivno reći ${ }^{45}$

Razumjeti papu Franju, njegovo djelovanje, stil i izjave moguće je samo ako se razumiju dubok smisao i značenje događaja i nauka Drugoga vatikanskog koncila, kao i zahtjevi za obnovom Crkve koje je on odredio i jasno formulirao. Stoga se umjesto pitanjem »Je li papa Franjo katolik? « trebalo zapitati već jučer, a ne tek danas: »Koliko su duh i slovo Koncila proželi pastoralnu i uopće katoličku svijest i mentalitet Crkve u Hrvatskoj?« Promatranje pape Franje omogućava prepoznavanje brojnih podudarnosti sa zahtjevima koncilske obnove Crkve. Može se reći da je papa Franjo, kao pojava, dozreo plod Crkve kakvu je svojim duhom i slovom posijao Koncil, Crkvu koja ne osuđuje, nego naviješta Radosnu vijest svim ljudima dobre volje i donosi im lijek milosrđa? ${ }^{26}$ Crkva koja »se poučena Duhom Svetim trsi da iz dana u dan prispijeva sve dubljem razumijevanju Svetih pisama kako bi svoju djecu neprestano hranila božanskim riječima«. ${ }^{47}$ Crkva koja ide ususret svim ljudima, naročito onima u potrebi i rubnima. ${ }^{48}$ Crkva koja zapodijeva iskren dijalog sa svijetom da bi vjerodostojnije naviještala evanđelje, ${ }^{49}$ a posebno s odijeljenim kršćanima (ekumenizam) $)^{50}$ i s drugim religijama (međureligijski dijalog). ${ }^{51}$ Crkva koja također ponizno priznaje da je učenica u svijetu, »jer dobro zna koliko je primila od povijesti i od razvitka ljudskog roda . $^{52} \mathrm{U}$ tom duhu papa Franjo poziva Crkvu na misijsku preobrazbu da

\footnotetext{
${ }^{44}$ Joseph RATZINGER, Koncil na putu. Osvrt na drugo zasjedanje, Zagreb, Kršćanska sadašnjost, 2008, 16.

${ }^{45}$ Ratzinger, Prvo zasjedanje Drugoga vatikanskog koncila..., 31.

${ }^{46}$ Usp. Dogmatska konstitucija Lumen gentium o Crkvi, (21. studenoga 1964.), u: DRUGI VATIKANSKI KONCIL, Dokumenti, 1; 8, [dalje LG].

${ }^{47}$ Dogmatska konstitucija Dei Verbum o božanskoj objavi, (18. studenoga 1965.), u: DRUGI VATIKANSKI KONCIL, Dokumenti, 23, [dalje DV].

${ }^{48} \mathrm{GS}, 88$.

${ }^{49}$ Usp. PAVAO VI., Ecclesiam suam - Crkvu svoju. Enciklika o putovima kojima Katolička crkva treba izvršavati u naše doba svoju zadaću, (6. kolovoza 1964.), Zagreb, Kršćanska sadašnjost, 1979, [dalje ES]. Također usp. GS, 1-11.

${ }^{50}$ Usp. Dekret Unitatis redintegratio o ekumenizmu, (21. studenoga 1964.), u: DRUGI VATIKANSKI KONCIL, Dokumenti, 1; 4 [dalje UR].

${ }^{51}$ Usp. Deklaracija Nostra aetate o odnosu Crkve prema nekršćanskim religijama, (28. listopada 1965.), u: DRUGI VATIKANSKI KONCIL, Dokumenti, 1-5, [dalje NA].

${ }^{52} \mathrm{GS}, 44$.
} 
bi širom otvorila svoja vrata, poput otvorena Očeva doma, i izišla naviještati evanđelje svima, da bi odvažno preuzela inicijativu (primerear), da bi svima pružila božansko milosrđe, da bi pastiri bili prepoznatljivi po mirisu svojih ovaca, da bi se pastoral i strukture obnovili i postali misionarski usmjereni, da bi bila usredotočena na ono što je uistinu bitno u vjerskom i moralnom učenju, da bi na mjesto lažne sigurnosti prihvatila oslobađajuću istinu nesigurnosti u vršenju svoga poslanja u svijetu. ${ }^{53}$ Ono što je Koncil jasno formulirao u svojim dokumentima papa Franjo prevodi u egzistenciju Crkve, čuvajući nutarnji kontinuitet vjere s neumornim upućivanjem na najbitnije: Radost evanđelja!

\section{6. »Nemoj zaboraviti siromašne!« (kardinal Claudio Hummes)}

Papa Franjo jasnim i nedvosmislenim jezikom poziva Crkvu da ostane vjerna opredjeljenju za siromašne kao »osobitom obliku povlaštenosti u oživotvorenju kršćanske ljubavi, o čemu svjedoči cijela crkvena predaja «. ${ }^{54}$ Opredjeljenje za siromašne je »sadržano u kristološkoj vjeri u onoga Boga koji je postao siromašan za nas, da nas obogati svojim siromaštvom (usp. 2 Kor 8,9$)$ «. ${ }^{55} \mathrm{U}$ tom smislu papa Franjo ide korak dalje i izjavljuje da »želi siromašnu Crkvu za siromašne«, budući da ßBog svoje milosrđe pokazuje najprije siromasima ${ }^{56} \mathrm{U}$ pogledu odnosa Crkve prema siromaštvu i siromasima valja se prisjetiti događaja pred sam kraj Koncila, točnije 16. studenoga 1965. godine, kada je četrdesetak koncilskih otaca, pretežito iz Latinske Amerike, među kojima je bilo i kardinala, u Domitillinim katakombama sklopilo »Dogovor iz katakomba « o opredjeljenju za siromašan život prema zahtjevima evanđelja. Umjesto pompe, bogatstva, trijumfalizma i mondene pojavnosti, koncilski su se oci obvezali na življenje evanđeoske jednostavnosti, skromnosti i siromaštva. U toj gesti i njihovoj zajedničkoj izjavi nema apsolutno ničega što bi proturječilo evanđelju.

Ne samo da nije na odmet, nego je od prvorazredne važnosti spomenuti također činjenicu da je papa Franjo kao buenosaireski nadbiskup davao svjedočanstvo skromnoga života, živeći u malom unajmljenom stanu, a ne u nadbiskupskoj palači, koristeći se javnim prijevozom, a ne limuzinom i osobnim vozačem, i susrećući se redovito s jednostavnim ljudima. Prema tome, njegov papinski stil, geste i naglasci proizlaze iz njegova osobnog pastoralnog i pastir-

\footnotetext{
${ }^{53}$ Usp. EG, 19-49.

${ }^{54}$ IVAN PAVAO II., Sollicitudo rei socialis - Socijalna skrb. Enciklika o dvadesetoj obljetnici enciklike Populorum progressio, (30. prosinca 1987.), Zagreb, Kršćanska sadašnjost, 1988, 42, [dalje SRS].

${ }^{55}$ BENEDIKT XVI., Discorso ai partecipanti della sessione inaugurale dei lavori della V Conferenza generale dell'episcopato Latinoamericano e dei Caraibi, (13. svibnja 2007.), http://www.vatican.va/content/benedict-xvi/it/speeches/2007/may/documents/hf_ben-xvi_spe_20070513_ conference-aparecida.html (16.04.2021).

${ }^{56} \mathrm{EG}, 198$.
} 
skog iskustva, logički su slijed i nastavak njegova već izgrađenoga i izoštrenog stila pastirskoga djelovanja.

Vrijedan je također spomena događaj koji se zbio tijekom oglašavanja rezultata izbora u petome izbornom krugu na konklavama 13. ožujka 2013. godine. U Sikstinskoj je kapeli pored kardinala Bergoglia sjedio umirovljeni nadbiskup Sao Paola u Brazilu i prefekt Kongregacije za kler, kardinal Claudio Hummes. Kad je čuo da mu prijatelj kardinal Bergoglio osvaja dvotrećinsku većinu glasova, ustao je, zagrlio ga i čestitao te mu je šapnuo: »Nemoj zaboraviti siromašne! « ${ }^{57}$

Evanđeoski poziv na siromaštvo i misao na siromašne uvjetovali su onda i izbor papinskog imena. Nije to ni po sv. Franji Ksaverskom, poznatom isusovačkom misionaru u Aziji iz 16. stoljeća, ni po sv. Franji Saleškom, ženevskom biskupu i crkvenom naučitelju iz 16. stoljeća, nego po sv. Franji Asiškome, poznatijem pod imenom Siromašak, utemeljitelju franjevačkoga Reda male braće na početku 13. stoljeća. Paradoksalno koliko već može biti, isusovac Bergoglio uzeo je franjevačko ime. Ako je točna ona latinska izreka Nomen est omen, to jest »Ime je znak«, onda su prva obilježja pontifikata pape Franje jednostavnost i siromaštvo, a za utjehu mnogim zabrinutima neka bude spomenuto da su te vrline resile i arškoga župnika sv. Ivana Mariju Vianneyja kojega je u svoje vrijeme, prigodom Svećeničke godine 2009., papa u miru Benedikt XVI. bio predložio za uzor, primjer i zaštitnika svim rimokatoličkim svećenicima. Komu u Crkvi smetaju jednostavnost i siromaštvo kao neupitne evanđeoske vrline?

U rujnu 2013. godine, šest mjeseci nakon izbora na Petrovu stolicu, papa Franjo je donio odluku, možda i najdalekosežniju za papinstvo uopće, o reviziji apostolske konstitucije pape Ivana Pavla II. iz 1988. godine Pastor Bonus - Dobri Pastir o Rimskoj kuriji, ${ }^{58}$ a zajedno s time i odluku o imenovanju »Kardinalskog vijeća za pomoć u upravljanju sveopćom Crkvom i izradu prijedloga obnove Rimske kurije. ${ }^{59}$ Tko je pratio zadnje dvije konklave, one 2005. godine kad je izabran Benedikt XVI. i ove posljednje 2013. godine kad je izabran Franjo, poznato mu je da je jedna od glavnih tema takozvanih kardinalskih kongregacija uoči konklava bila upravo reforma Rimske kurije. Nezadovoljstvo radom i djelovanjem Rimske kurije već je odavno poznato, o tome je potrošeno mnogo

\footnotetext{
${ }^{57}$ Papa FRANJO, Discorso ai rapresentanti dei media, (16. ožujka 2013.), http://www.vatican.va/ content/francesco/it/speeches/2013/march/documents/papa-francesco_20130316_rappresentanti-media.html (12.04.2021).

${ }^{58}$ Usp. IVAN PAVAO II., Pastor Bonus. Costitutione apostolica sulla Curia Romana, (28. lipnja 1988.), http://www.vatican.va/content/john-paul-ii/it/apost_constitutions/documents/hf_jpii_apc_19880628_pastor-bonus.html (18.04.2021).

${ }^{59}$ Usp. Papa FRANJO, Chirografo con il quale viene istituito un Consiglio di cardinali per aiutare il Santo Padre nel governo della Chiesa universale e per studiare un progetto di revisione della costituzione apostolica Pastor Bonus sulla Curia Romana, (28. rujna 2013.), u: https://www.vatican.va/content/francesco/it/letters/2013/documents/papa-francesco_20130928_chirografoconsiglio-cardinali.html (18.04.2021).
} 
tinte i ne treba to ovdje ponavljati. ${ }^{60}$ Papa Franjo je, a kako priliči i što mu treba upisati u zaslugu, reformu Kurije započeo od samoga sebe i to već od časa svoga izbora na Petrovu stolicu. Spomenimo samo da se nije smjestio u raskošnu takozvanu apostolsku palaču, nego u skromniji vatikanski hostel. Slijedom toga se pitamo komu u Crkvi smeta da se papa Crkvi i svijetu ne predstavlja kao faraon ili predsjednik, nego onako kako mu samo ime službe kaže, dakle kao jednostavan otac ili, još rječitije, kao pauper pauperum - siromah siromaha, kao pristupačan pastir usred svoga stada? Pompa, raskoš i komfor možda jesu medijski privlačni, ali se teško opravdavaju pred zahtjevima evanđelja i nikoga ne potiču na osobno obraćenje.

U svome prvom dokumentu, ako izuzmemo encikliku Lumen fidei - Svjetlo vjere koja je većinom nastala iz pera pape u miru Benedikta XVI., dakle u apostolskoj pobudnici znakovitoga naslova Evangelii gaudium - Radost evanđelja, papa Franjo je jednostavnim jezikom predstavio svoju viziju Crkve, a kako je uobičajeno, i program svoga papinskog služenja. Umjesto medijski atraktivnog pitanja »Je li papa Franjo katolik? « držimo da je bilo daleko korisnije i poučnije usredotočiti se na glavne misli i poruke spomenute pobudnice. To bi nesumnjivo pomoglo u boljem razumijevanju pape Franje kao istinskoga katolika, s jedne, i u razumijevanju njegova dosadašnjeg papinskog služenja, s druge strane. Sve ili gotovo sve njegove jedinstvene i do sada rijetko viđene papinske geste koje su izazvale u nekim crkvenim krugovima negativne, a kod nekih i ružne reakcije, nedvosmisleno potvrđuju da je u samu narav Crkve upisana trajna obnova. Nažalost, čini se da u Crkvi ima mnogo vjernika koji bolje znaju što papa treba činiti, nego što poznaju osobnu odgovornost, kao krštenika, u obnovi Crkve koja se pokazuje u osobnom svjedočenju i naviještanju Radosne vijesti poradi izgradnje Božjega kraljevstva u svijetu. Nitko ne potvrđuje ljubav prema Crkvi izražavanjem nezadovoljstva prema pozivu na evanđeosko obraćenje i obnovu crkvenih struktura da bi pastoralno djelovanje Crkve pružalo odgovore na stvarne potrebe današnjih ljudi.

Sintagma da se Crkva treba stalno obnavljati (Ecclesia semper reformanda est), s dodatkom da to uključuje glavu i udove, dotično hijerarhiju i sve vjernike (in capite et in membris), u papi Franji nalazi rječit izraz i potvrdu. Valjalo bi se upitati je li papa katolik koji bi samovoljno proglasio nepotrebnom i suvišnom obnovu Crkve što ju je naložio Drugi vatikanski koncil? Papa Franjo koji svojim djelovanjem obnavlja i pomlađuje Crkvu te svima pruža vidljive znakove za odvažne iskorake u svojim sredinama, zaista nije zaslužio neumjesne i često otrovne kritike. Pritom je važno sačuvati otvorenost srca Božjoj riječi koja nam kaže:

\footnotetext{
${ }^{60}$ Usp. John R. QUINN, The Reform of the Papacy. The Costly Call to Christian Unity, The Crossroad Publishing Company, New York, 1999. O tome također usp. Nediljko A. ANČIĆ, Rimska kurija i rasprave o papinu primatu, Crkva u svijetu, 46 (2011) 1, 59-73.
} 
»Nitko tko u Duhu Božjem govori ne kaže: 'Prokletstvo Isusu.' I nitko ne može reći: 'Gospodin Isus', osim u Duhu Svetom. Različiti su darovi, a istini Duh; i različite službe, a isti Gospodin; i različita djelovanja, a isti Bog, koji čini sve u svima« (1 Kor 12,3-6).

Je li umjesno, da ne kažemo krajnje provokativno, upitati se: stanuje li isti Duh, isti Gospodin i isti Bog u papi Franji i onima koji ga grubo napadaju i sumnjiče za katoličku vjerodostojnost?

\section{7. »Ako sam krivo rekao, dokaži da je krivo! Ako li pravo, zašto me udaraš? « (Iv 18,23)}

U pobudnici Evangelii gaudium papa Franjo je pobrojao bitne izazove današnjice, ${ }^{61}$ a odmah zatim donosi cijelu listu iskušenja s kojima se danas suočavaju i pastoralni djelatnici, pozvavši, među ostalim, sve da kažemo odlučno »ne« svjetovnoj duhovnosti

»koja se skriva iza privida pobožnosti ili čak ljubavi prema Crkvi, a sastoji se u traženju ne Gospodinove slave, nego ljudske i osobne dobrobiti. To je ono što je Gospodin predbacivao farizejima. 'Ta kako biste vi vjerovali kad tražite slavu jedni od drugih, a slave od Boga jedinoga ne tražite!' (Iv 5,44). Riječ je o suptilnom načinu da se traži 'svoje, a ne ono što je Isusa Krista' (Fil 2,21).« ${ }^{62}$

Možda je moguće drukčije, ali držimo ne i jasnije izjaviti da pobožni stavovi i verbalno isticanje ljubavi prema Crkvi kod Franjinih kritičara služe kao pokrivalo za nešto drugo pa i za puke ljudske interese. Znajući da je tako, dakle da posrijedi nije traženje Gospodinove slave i dobrobiti Crkve kao Božjega naroda, nego traženje partikularnih i sebičnih probitaka, zar nije služenje istini kad se takve pojave nazovu pravim imenom? U nastavku je papa Franjo još otvoreniji i jasniji:

»Ta mračna svjetovnost očituje se u mnogim stavovima koji su naizgled međusobno suprotstavljeni, ali im je zajednička težnja da 'osvoje prostor Crkve'. Kod nekih ljudi primjećujemo razmetljivu brigu za bogoslužje, učenje i ugled Crkve, ali ne pokazuju nikakvu brigu za stvarno ucjepljivanje evanđelja u Božji narod i u konkretne potrebe sadašnjeg trenutka. Na taj se način Crkva pretvara u muzejski izložak ili nešto što je u posjedu izabrane nekolicine pojedinaca. Kod drugih se ista duhovna svjetovnost krije iza očaranosti društvenim i političkim postignućima ili slavohlepnosti sposobnošću postizanja zavidnih praktičkih rezultata ili pak opsjednutost tečajevima samopomoći i samoostvarenja. To se može pretvoriti i u brigu za pokazivanjem u javnosti, u bogat društveni život pun putovanja, sastanaka, večera, primanja. To se može očitovati i u menadžerskom funkcioniranju zaokupljenom statistikama, planiranjima i osjenjivanjima,

\footnotetext{
${ }^{61}$ Usp. EG, 52-101.

${ }^{62} \mathrm{EG}, 93$.
} 
od čega glavnu korist nema Božji narod, već prije Crkva kao organizacija. U svim tim slučajevima znak Krista utjelovljenoga, raspetog i uskrslog nije vidljiv; stvaraju se elitne skupine, ne čine se nikakvi napori u traženju onih koji su se udaljili od Crkve ili golemog mnoštva onih koji žeđaju za Kristom. ${ }^{63}$

Teret dokazivanja ove i svih drugih papinih kritičkih analiza nije na njemu, nego na onima koji se s njime ne slažu. Prije nego papu Franju proglase nekatolikom, red je da dokažu da nije u pravu. Dobro nam je poznata epizoda s Isusom pred Kajfom, velikim svećenikom, kad mu je odgovorio da je javno govorio i naučavao pa neka onda upita narod o sadržaju, a »jedan od nazočnih stražara udari Isusa po obrazu govoreći: 'Tako li odgovaraš velikom svećeniku?' Odgovori mu Isus: 'Ako sam krivo rekao, dokaži da je krivo! Ako li pravo, zašto me udaraš?'« (Iv 18,22-23). Pitamo se komu u Crkvi smeta poziv na odlučno »ne« svjetovnoj duhovnosti koja Crkvu pretvara u muzej, uvlačeći u nju prijetvornu logiku karijerizma, vlastohleplja, pretjeranoga liturgizma, jednostrane obrane vjere bez ljubavi, duhovnog menadžerstva, lažne ponude instant obraćenja i brzoga ozdravljenja? Papa Franjo je ovim opisom dirnuo u osinjak mentaliteta brojnih pastoralnih djelatnika i njihovih suradnika kojima je lakše uzvratiti papi Franji, negoli priznati sebi da smo na krivome putu i da trebamo učiniti zaokret ravan evanđeoskome obraćenju?

Papa Franjo poziva upravo mlade da se uključe u obnovu Crkve i tako pruže dragocjenu pomoć u njezinoj obnovi od epohalnoga značenja, ${ }^{64}$ a u kontekstu govora o suzbijanju svakog oblika zlostavljanja. ${ }^{65}$ Otvorenost novoj Pedesetnici i početku nove faze čišćenja i promjene preduvjet je da mladi mogu pomoći u obnovi Crkve, a

»još i više ako se osjete dijelom svetoga i strpljivoga Božjeg naroda, koji je poduprt i oživljen Duhom Svetim, jer upravo će nas taj sveti Božji narod osloboditi od kuge klerikalizma, koji je plodno tlo za sve gadosti«. ${ }^{66}$

Ako se mnogi ili samo neki mladi u traženju veće jasnoće i sigurnosti pitaju je li papa Franjo katolik, spontano nam se nameće pitanje o karakteru tog možebitnog nesporazuma između naših mladih i pape Franje? Pitamo se jesu li imali u rukama i pročitali njima upravljenu pobudnicu Krist živi? Imajući pred sobom sadržaj i poruke samo ove Franjine pobudnice, teško nam je zatomiti čuđenje spram naglašene zbunjenosti mladih. Mladi spontano cijene jednostavnost, skromnost, pristupačnost, neposrednost, otvorenost, odvažnost i dosljednost, dok svako dobronamjerno srce ove vrline bez muke može prepoznati u djelovanju pape Franje. Osim toga, već je Koncil izjavio da

\footnotetext{
${ }^{63} \mathrm{EG}, 95$.

${ }^{64}$ Usp. ChV, 102.

${ }^{65}$ Usp. ChV, 95-102.

${ }^{66} \mathrm{ChV}, 102$.
} 
"promjena mentalitetâ i strukturâ često dovodi u pitanje predane vrijednosti, napose u mladeži koja je često nestrpljiva i koja, štoviše, zbog tjeskobe postaje buntovnom te, svjesna vlastite važnosti u društvenom životu, želi brže imati udjela u njemu«. ${ }^{67}$

U tom smislu bi se očekivalo da Papino neprestano sijanje riječi obraćenja, obnove, preobrazbe, jednostavnosti, milosrđa, transparentnosti, to jest riječi kojima poziva na veću dosljednost i vjerodostojnost Crkve, osobito pastoralnih djelatnika, upravo u mladima nailaze na dobru zemlju iz koje će rasti očekivani dobri i obilati plodovi (usp. Mt 13,8). Teško je sakriti čuđenje da papa Franjo kod nas u Hrvatskoj, čak i kod nekih mladih, nailazi na, ako već ne na otpor, onda na stanovitu zbunjenost koja lako može odvesti u ravnodušnost. Bilo bi ravno radosti uskrsnuća kad bi ovo bila kriva procjena.

Gola je činjenica da su mladi također povodljivi zbog razumljivih nedostataka ljudske zrelosti u njihovoj životnoj dobi. Mišljenja i stavovi mladih se redovito oslanjaju na mišljenja i stavove starijih, osobito onih iz neposredne blizine u koje imaju povjerenja. Neizbježno je stoga da mladi u sebi nose obilježja dominantnoga mentaliteta i svijesti mjesne Crkve i društva u kojemu žive. U tom smislu sa žalošću konstatiramo da u našoj mjesnoj Crkvi papa Franjo, osobito među brojnim pastoralnim djelatnicima, ne nailazi na dužnu otvorenost i prihvaćanje. No, takav odnos nema veze ni s objektivnim sagledavanjem relevantnih činjenica, ni sa zahtjevima vjere ljubavlju djelotvorne, ni sa zahtjevom čuvanja jedinstva Crkve, ni sa zahtjevom sentire cum Ecclesia »osjećati s Crkvom« ${ }^{68}$ Takav odnos nije korektan ni pošten prema »rimskome prvosvećeniku, kao Petrovu nasljedniku, trajnom i vidljivom počélu i temelju jedinstva kako biskupâ tako i mnoštva vjernikâ«. ${ }^{69}$ Ako se sad ustežemo od svake polemike, ipak, ne možemo se ustegnuti od evanđelja. Upozorenje našega Gospodina Isusa na ovome mjestu poprima snažne i jasne odjeke:

»Čuvajte se lažnih proroka koji dolaze $\mathrm{k}$ vama $\mathrm{u}$ ovčjem odijelu, a iznutra su vuci grabežljivi. Po njihovim ćete ih plodovima prepoznati. (...). Ne može dobro stablo donijeti zlih plodova, niti nevaljalo stablo dobrih plodova« (Mt 7,15.18).

Od ovog suda nitko nije pošteđen pa ni djelovanje i pontifikat pape Franje. Posljednju riječ o njemu dat će Bog, ali i budućnost kojoj idemo ususret. Točno onako kako sadašnjost Crkve, koja je opterećena nemilim aferama, od seksualnog zlostavljanja ${ }^{70}$ preko malverzacija vatikanskim financijama do eklatantnih primjera zloporabe moći i savjesti, baca ružnu sliku i tamne sjene na pontifikate Franjinih predšasnika.

\footnotetext{
${ }^{67} \mathrm{GS}, 7$.

${ }^{68}$ Usp. Anton TAMARUT, Sentire cum Ecclesia - osjećati s Crkvom. Suvremeni naglasci, Bogoslovska smotra, 76 (2006) 1, 61-79.

${ }^{69}$ LG, 23.

${ }^{70}$ Usp. Tonči MATULIĆ, Neki najrecentniji aspekti fenomena pedofilije u Crkvi, Bogoslovska smotra, 88 (2018) 4, 899-914.
} 


\section{8. »Budite milosrdni kao što je Otac vaš milosrdan« (Lk 6,36)}

Ne slažemo se s mišljenjem po kojemu bi nutarnja nagnuća i opredjeljenja mladih bila za autoritarnost, zataškavanje, malverzacije, zbijene redove, trijumfalizam, zloporabe moći i savjesti. S ovim se polugama možda postiže veća sigurnost, ali se ne pokazuje istina i ne daje se prostora istinskoj slobodi. Uvjereni smo da su nutarnja nagnuća i spontana opredjeljenja mladih za jednostavnost, skromnost, transparentnost, iskrenost, otvorenost, neposrednost, pristupačnost, odlučnost i dosljednost. To su poželjne vrline koje pokazuju istinu i daju prostora istinskoj slobodi. Valja sasvim otvoreno priznati da između sigurnosti i slobode postoji dijalektička napetost. Tko traži više sigurnosti morat će se odreći slobode: »Doista, vi ste, braćo, na slobodu pozvani!« (Gal $5,13)$. Ne na sigurnost, nego na slobodu, dakako, na slobodu koja nije izlika zlu, nego mogućnost da u ljubavi i iskrenosti služimo jedni drugima (usp. Gal 5,13).

Svaka osoba dobre volje bez poteškoća može prepoznati nabrojene vrline u nastojanjima pape Franje. Tko je isključivo zaokupljen karizmom papine nezabludivosti i sa strepnjom od pape očekuje samo da mu ulijeva sigurnost, treba znati da se ona prvenstveno tiče svečanog iznošenje nauka ex cathedra:

»Naučavamo i definiramo da je od Boga objavljena dogma da se rimski prvosvećenik, kada govori sa Stolice (ex cathedra), to jest kada vrši službu pastira i učitelja svih kršćana, i kada svojim vrhovnim apostolskim autoritetom definira učenje o vjeri i ćudoređu koje treba držati cijela Crkva, odlikuje onom nezabludivošću koja mu je obećana po blaženom Petru, i kojom je božanski Otkupitelj želio da bude opremljena njegova Crkva kod definiranja učenja o vjeri i ćudoređu; zbog toga su takve definicije rimskog prvosvećenika nepromjenjive po sebi, a ne po suglasnosti Crkve. $\ll^{71}$

Prema tome, zahtijevati i očekivati od bilo kojega pape, uključujući i papu Franju, da u svakoj svojoj riječi, izjavi, gesti, reakciji, nagovoru ili odluci bude nezabludiv ili da nam ulijeva blaženi dojam nezabludivosti, nije u skladu s definicijom dogme o nezabludivosti, kao ni s činjenicom da je papa upravo kao ljudsko biće dio - ud - Crkve, a nipošto ne iznad Crkve, te stoga neizbježno ima i svoje ljudske slabosti i ograničenja. Razumljivo je samo po sebi da papa može imati pogrešna privatna mišljenja. ${ }^{72}$ Komu smetaju neizbježne ljudske slabosti i ograničenja pojedinoga pape, treba znati da nije do pape da mu se opravdava, nego do njega da suvislo i primjereno dokaže da ih papa kao ljudsko biće i član Crkve ne smije imati. Pritom neka vodi računa o činjenici da na licu Zemlje ne postoji nepogrešivo ljudsko biće. U Crkvi postoji samo vjera u istinu evanđelja i na njoj utemeljena istina nezabludivosti pape kao vrhovnog pastira Crkve. Posrijedi je, dakle, vjerska, a ne ljudska nezabludivost.

\footnotetext{
${ }^{71}$ PRVI VATIKANSKI KONCIL, Prva dogmatska konstitucija Pastor aeternus o Kristovoj Crkvi, (18. srpnja 1970.), u: DH, 3073-3074.

${ }^{72}$ Usp. Benedikt XVI., Svjetlo svijeta..., 21.
} 
S nezabludivošću je, dakako, neraskidivo povezana istina o Božjemu milosrđu na koju je papa Franjo pozvao cijelu Crkvu da je opet stavi u samo središte svoga života i pastoralnog djelovanja. Božansko milosrđe je u samome središtu objave Boga kao milosrdnoga Oca Gospodina našega Isusa Krista. U tom je smislu papa Franjo na svetkovinu Bezgrešnog začeća Blažene Djevice Marije 8. prosinca 2015. godine proglasio Izvanredni jubilej Svete godine Božjega milosrđa, izjavivši u buli najave jubileja Misericordiae vultus - Lice milosrda:

»Milosrđe je sam temelj na kojem počiva život Crkve. Cjelokupno njezino pastoralno djelovanje moralo bi biti obavijeno nježnošću koju pokazuje prema vjernicima; ništa u njezinu naviještanju i njezinu svjedočenju svijetu ne bi smjelo biti lišeno milosrđa. Sama se vjerodostojnost Crkve očituje u tome kako ona pokazuje milosrdnu i suosjećajnu ljubav. ॥ $^{73}$

Pitamo se komu u Crkvi smeta najizvornija kršćanska poruka o Božjemu milosrđu? Zar u samome srcu evanđelja ne stoji upravo Božje milosrđe posredovano životom i djelom Isusa Krista Sina Božjega? Nije li napose Lukino evanđelje najrječitije svjedočanstvo o neshvatljivoj veličini dara Božjega milosrđa u Isusu Kristu? »Budite milosrdni kao što je Otac vaš milosrdan« (Lk 6,36).

Pred Bogom je uzaludno samozavaravati se, jer Bog nije pristran niti se dade izrugivati (usp. Gal 6,7). Stoga valja otvoreno priznati da je Crkva tek u novije vrijeme, ponovno otkrila i valorizirala Božje milosrđe u samome središtu evanđelja i božanske objave. ${ }^{74} \mathrm{U}$ tom je smislu papa sv. Ivan XXIII. 1962. godine pozvao Crkvu da danas radije koristi lijek milosrđa, nego oružje osude. Koncil je odustao od prakse osude koja je bila vlastita koncilskim izjavama sve tamo od prvoga koncila u Niceji 325. godine. Papa sv. Ivan Pavao II. je svoju drugu encikliku, a nakon prve Redemptor hominis - Otkupitelj čovjeka, ${ }^{75}$ naslovio Dives in misericordia - Bogat milosrdem i posvetio ju je otkrivanju dubine, visine, širine i dužine Božjega milosrđa u naviještanju Radosne vijesti u suvremenom svijetu. ${ }^{76} \mathrm{Na}$ krilima ponovno valoriziranog Božjega milosrđa papa Franjo je izjavio: »Prva je istina Crkve Kristova ljubav. Crkva je služiteljica te ljubavi i posreduje tu ljubav ljudima: ljubav koja oprašta i izražava se kroz sebedarje. Zato, gdje god je Crkva prisutna, ondje mora biti vidljivo Očevo milosrđe. ${ }^{17} \mathrm{Na}$ mjestu je prosudba da je papa Franjo pokrenuo »revoluciju« nježnosti i ljubavi

\footnotetext{
${ }^{73} \mathrm{MV}, 10$.

${ }^{74}$ Usp. Walter KASPER, Barmherzigkeit. Grundbegriff des Evangeliums - Schlüssel christlichen Lebens, Freiburg i./B., Herder Verlag, 2012. Također usp. Walter KASPER, Milosrđe. Temeljni pojam evanđelja - ključ kršćanskoga života, Zagreb, Kršćanska sadašnjost, 2015.

${ }^{75}$ Usp. IVAN PAVAO II., Redemptor hominis - Otkupitelj čovjeka. Enciklika na početku papinske službe, (4. ožujka 1979.), Zagreb, Kršćanska sadašnjost, 1980, [dalje RH].

${ }^{76}$ Usp. IVAN PAVAO II., Dives in misericordia - Boga milosrđem. Enciklika o Božjem milosrđu, (30. studenoga 1980.), Zagreb, Kršćanska sadašnjost, ${ }^{2}$ 1994, [dalje DM].

${ }^{77} \mathrm{MV}, 12$.
} 
u Crkvi. ${ }^{78}$ Njegovo inzistiranje na Božjemu milosrđu u životu i poslanju Crkve upućuje na najprivlačniju i najtopliju istinu cjelokupne kršćanske objave. ${ }^{79}$

\section{9. »A povrh svega - ljubav! To je sveza savršenstva« $($ Kol 3,14)}

Vjerničko prozivanje i napadanje pape Franje otkriva nedostatke $u$ ispravnom razumijevanju jedinstva Crkve kojemu je upravo papa vodljiv znak i garant. Ubi Petrus, ibi Ecclesia! Zbog toga napadi daju žalosno svjedočanstvo manjka ispravnog osjećaja crkvenosti i iskustva prave Crkve kao zajedništva i jedinstva vjere, nade i ljubavi u različitosti. Napadi se redovito zaogrću riječima obrane Crkve i vjere. Kakva je to obrana Crkve i vjere koja iznutra otvoreno napada samu Glavu?

»Red biskupâ, koji je u učiteljstvu i u pastirskoj upravo naslijedio zbor apostolâ i u kojem se dapače apostolski zbor neprekinuto nastavlja, subjekt je također vrhovne i pune vlasti u cijeloj Crkvi, zajedno sa svojom Glavom, rimskim biskupom, a nikada bez te Glave; ta se vlast može obnašati samo uz pristanak rimskoga prvosvećenika.« ${ }^{80}$

Stanuje li u srcima kritičara prva i osnovna istina Crkve, a to je Kristova ljubav? Pitanje nije retoričko, nego supstancijalno. Kako opravdati kritike i napade na Glavu u svjetlu teološko-ekleziološkog značenja službe Petrova nasljednika i zahtjeva kršćanske ljubavi kao sveze savršenstva među svim vjernicima (usp. Kol 3,14)?

Istina zahtijeva da se odgonetne tko odapinje otrovne strijele i nabacuje se blatom kritika na papu Franju? No, što bismo dobili s time? One koje smo upoznali iz svjetskih medija i literature nisu vrijedni naše pažnje upravo zbog prerušene zlovolje u pobožnost koja hoće »osvojiti prostor Crkve ${ }^{81}$ i koja »odbacuje proročki glas braće, diskvalificira onoga koji ga postavlja u pitanje, neprestano ističe pogreške drugih i opsjednut je izgledom. (...). To je strašna iskvarenost prerušena u dobro. ${ }^{82}$ Ipak, Gospodin Isus nam je obećao da se ne bojimo onih koji ubijaju tijelo (usp. Mt 10,29).

Neki u napadima idu čak tako daleko da papu Franju prozivaju za uvođenje poganstva u Crkvu, kritizirajući žestoko gestu izlaganja statue Pachamame, andske božice zemlje, za vrijeme održavanja Biskupske sinode o Amazoniji u Vatikanu u listopadu 2019. godine. Suvišno je braniti ovu gestu kao nešto izdvo-

\footnotetext{
${ }^{78}$ Usp. Kardinal Walter KASPER, Papa Franjo. Revolucija nježnosti i ljubavi, Zagreb, Kršćanska sadašnjost, 2015.

${ }^{79}$ Usp. Papa FRANJO, Crkva milosrđa, Zagreb, Kršćanska sadašnjost, 2014; Papa FRANJO, Božje ime je milosrde. Razgovor a Andreom Torniellijem, Split, Verbum, 2016; Papa FRANJO, Kateheze i nagovori o milosrđu, Zagreb, Kršćanska sadašnjost, 2017.

${ }^{80} \mathrm{LG}, 22$.

${ }^{81} \mathrm{EG}, 95$.

${ }^{82} \mathrm{EG}, 97$.
} 
jeno, već stvar treba promotriti u široj perspektivi. Naime, što vidimo kad gledamo nasred Trga sv. Petra poganski obelisk ispisan egipatskim hijeroglifima? Što razumijemo kad vidimo natpis poganske rimske religije Pontifex Maximus, kojega danas susrećemo doslovno na svakoj rimskoj crkvi i bazilici i na svakom zidu, koji je od renesansnoga razdoblja postao uobičajena papinska titula? Od vremena rimskoga cara Tiberija Augusta (17.-34.) koji je sebe bio proglasio božanstvom upravo u vrijeme utjelovljenja Sina Božjega u Isusu iz Nazareta, spomenutu titulu su nosili isključivo rimski carevi. Jesu li pape uveli poganstvo u Crkvu time što su preuzeli titulu vrhovnoga svećenika rimske poganske religije pridržanu obogotvorenome poganskom caru? Jesu li prvi misionari među poganima nakon propasti Zapadnoga Rimskoga Carstva i provale poganskih barbarskih plemena poganizirali kršćanstvo ili kristijanizirali poganstvo time što su nekim njihovim poganskim običajima dali bitno drugo - upravo kršćansko - značenje, a njihove poganske bogomolje pretvorili u crkve? Što bismo otkrili kad bismo počeli kopati dublje ispod brojnih naših lokalnih i globalnih kršćanskih običaja? Napadi ovakve vrste boluju od kroničnog nedostatka znanja iz crkvene povijesti kristijanizacije poganskih naroda. Ali takvo neznanje ne opravdava, jer je ono veoma lako savladivo. Ovaj napad stoga boluje od zlovolje koja sikće netrpeljivošću prema papi Franji. Nije ga moguće opravdati zdravom vjerom ni ispravnim osjećajem crkvenosti.

\section{Umjesto zaključka}

Bilo bi korisno i poučno predstaviti brojne geste i poruke pape Franje koje utiru put novom odnosu Crkve prema svijetu, ženama, mladima, migrantima, različitim periferijama, ekumenizmu, nekršćanskim religijama, vjernicima koji se osjećaju ostavljenima i zaboravljenima, ali je sasvim dovoljno ovoliko za upoznavanje veličine i intenziteta ljubavi, predanosti i požrtvovnosti pape Franje za Crkvu i njezinu istinsku dobrobit koju poznajemo iz srca evanđelja i nauka Drugoga vatikanskog koncila za kojega je sv. Ivan Pavao II. izjavio:

»Nakon zaključenja Jubileja (2000., op. a.) osjećam, više no ikad, dužnost ukazati na Koncil kao na veliku milost koju je zadobila Crkva u 20. stoljeću. U njemu nam je ponuđen siguran kompas da bi nas usmjerio tijekom hoda u stoljeću u koje ulazimo. $\ll^{83}$

Sve što smo do sad imali prilike vidjeti i čuti od pape Franje dokazuje da se on u ovome stoljeću čvrsto i postojano drži tog sigurnog kompasa. Slijedom toga, kritičarima pape Franje, ili samo zbunjenima zbog pape Franje, preostaje

\footnotetext{
${ }^{83}$ IVAN PAVAO II., Novo millenio ineunte - Ulaskom u novo tisućljeće. Apostolsko pismo na završetku Velikog jubileja godine 2000., (6. siječnja 2001.), Zagreb, Kršćanska sadašnjost, 2001, 57.
} 
upitati se: Kojeg se sigurnog kompasa držimo dok odapinjemo otrovne strelice kritika i nabacujemo se blatom svakakvih etiketa na istinskoga i vjerodostojnog katolika papu Franju? Poučeni evanđeljem da je sâm Sin Božji od »pravovjernih « svećeničkih i narodnih starješina bio proglašen bogohuliteljem (usp. Mk 14,63), izjelicom i vinopijom (usp. Lk 7,34), onda u kritičarima pape Franje treba prepoznati jednostrano raspaljene vjerskim žarom za očuvanjem pravovjerja i sigurnosti, što im priječi da u njemu prepoznaju zapaljenu vatru milosrdne ljubavi i breme prave slobode kao istinskoga znaka slike Božje u čovjeku. ${ }^{84}$ Neka bude: In necessariis unitas in dubiis libertas in omnibus caritas!

${ }^{84}$ Usp. GS, 17. 


\section{Tonči Matulić* \\ Is Pope Francis a Catholic? \\ Summary}

The article was expanded and equipped with sources and literature, a lecture entitled »is Pope Francis a Catholic«, held on April 21, 2021 on social networks of the Croatian Aboveground, the official project of the Youth Office of the Split-Makarska Archdiocese. In the article, the author shows and proves that the question »is Pope Francis a Catholic « on the one hand suffers from media sensationalism and on the other suffers from the unfounded and excessive zeal for the defence of ecclesiastical doctrine and discipline from, however, the ethically justified, theologically unquestionable and ecclesiologically acceptable different Catholic style and mentality of Pope Francis. In this sense, the author presents some historical examples, refers to church teaching sources, especially the teachings of the Second Vatican Council, presents critical theological analyzes and appropriate theological arguments to understand the true nature and motives of the concerns of church critics of Pope Francis. The will to »conquer the space of the Church" and preserve the status quo, the insistence on the shallow conviction »that so has always been done", the petrified mentality that rejects the call to conversion and missionary transformation of church structures and pastoral action are revealed as major obstacles to embracing a different style, new gestures and some unexpected - critical - statements of Pope Francis which unequivocally confirm him as a ripe fruit of the conciliar renewal of the Church and a true gift of the Holy Spirit to the Church for the $21^{\text {st }}$ century. In this sense the statement of the Second Vatican Council should be borne in mind: "While Christ, holy, innocent and undefiled (Heb. 7:26), knew nothing of $\sin (2$ Cor. 5:21), but came to expiate only the sins of the people (Cf. Heb. 2:17), the Church, embracing in its bosom sinners, at the same time holy and always in need of being purified, always follows the way of penance and renewal « (Lumen gentium, 8).

Key words: Pope Francis, Jesus Christ, Holy Spirit, Gospel, Faith, Love, Mercy, Poverty, Church, Second Vatican Council, Youth.

(na engl. prev. Tonči Matulić)

\footnotetext{
* Tonči Matulić, STD; Full Professor of Moral Theology, Bioethics, and Social Teaching of the Church; University of Zagreb, Catholic Theological Faculty, Vlaška 38, P. Box 432, HR-10000 Zagreb, Croatia; E-mail: tonci.matulic@kbf.unizg.hr.
} 